\title{
ملامح التفكير التداولي البياني عند الأصوليين
}

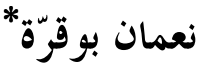

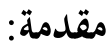

لعل أهم سؤال مبدئي يتبادر إلى الأذهان، قبل الخوض في الأبعـاد التداوليسـة في التراث العربي الإسلامي من زاوية لغوية أصولية، يتعلقُ بمفهوم بالتداوليــة، وعلاقتـــها

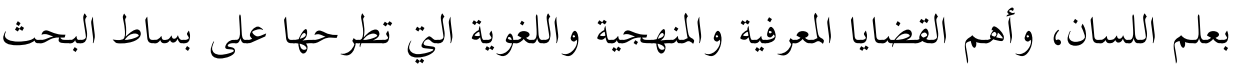

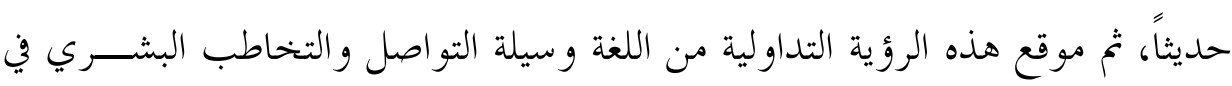
مسار تطور المعرفة اللغوية قديماً وحديثاً، وأصول هذا التوجه في دراسات القدات القدماء بعامة التهاء

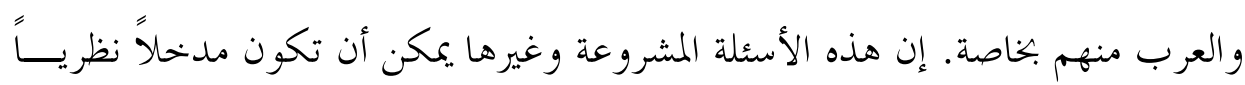
وتأسيسياً، هدف الكشف عن أبعاد النظر التداولي في المسألة اللغوية، مع إمكان إبراز بحمل المقولات التي تتأسس عليها التداولية في الفكر الحديث، ومحلها من النظرية البيانية العربية القديمة، بخاصة عند البلاغيين والمفسرين والأصوليين الذين استوت في تصوراهم الأسس التداولية لتحليل الخطاب القرآين، مفضية إلى معالم نظرية عربيـــة في الأفتـــال الكلامية، يمكن أن يستفاد منها في تطوير النظرية في صورةا الراهنة.

ور.بما أمكننا هذا الجههد من وضع الإطار المعرفي للسانيات تداولية عربية تــــرس الاستعمال اللغوي وأغراضه، متجاوزة وصف البنية والشكل النحوي، فاتحــــة أفتــاً

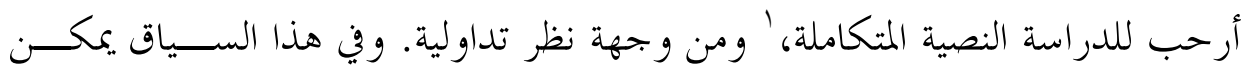

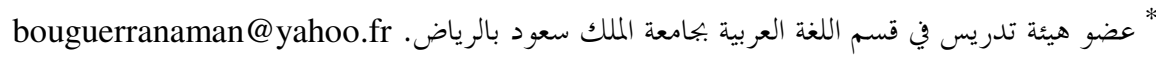

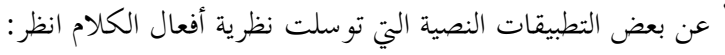

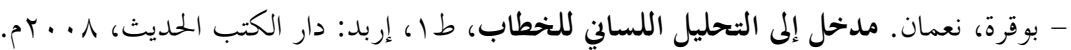


التنويه بمحاولات طه عبدالرحمن -الفيلسوف المغربي- في إعادة تفكيــك المــوروث التراثي من خلال جملة من الأبحاث الرائدة، لعل أهمها كتابه: "في أصول الحوار وبتحيد

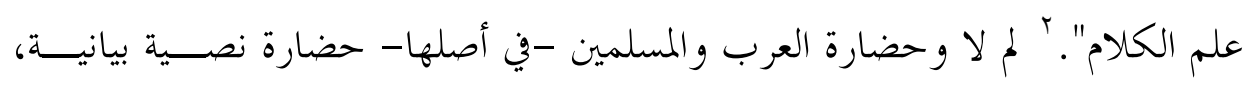
تقوم على مقاصد الخطاب ومغزاه في عملية الفهم والإفهام، ثم محاولة اســتثمار هــــهـ

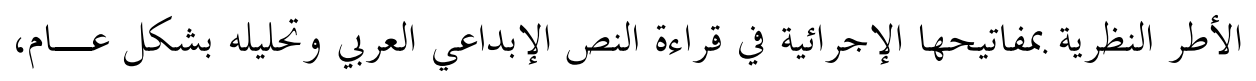

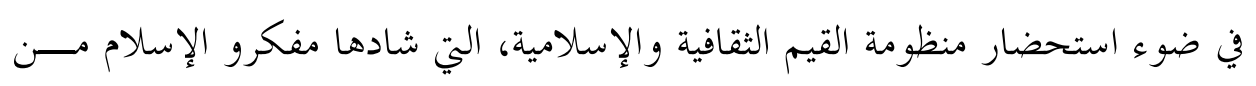
خلال وعيهم العميق بسياقات إنتاج الدلالة، واستقطار المعنى المركزي، و المعاني الحافة

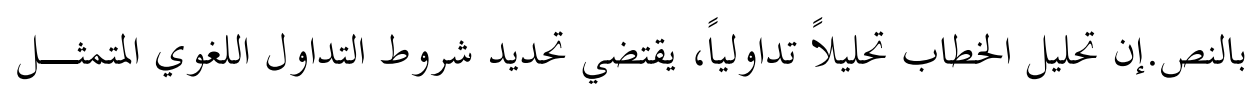

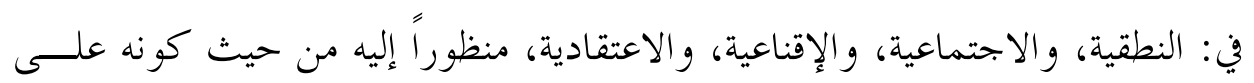

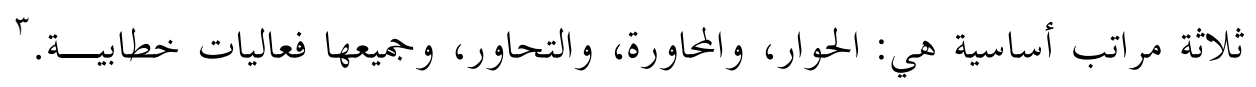

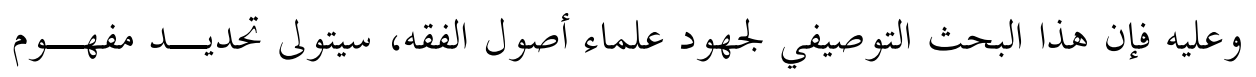

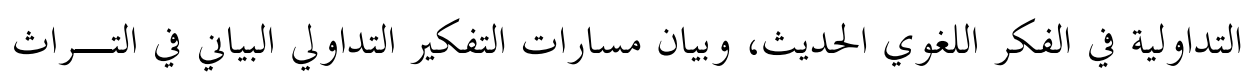
العربي، وتوضيح الأفعال الكلامية عند الأصوليين.

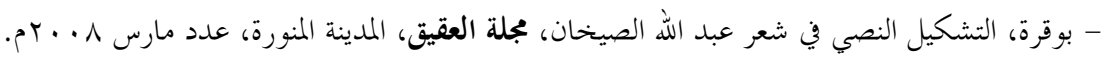

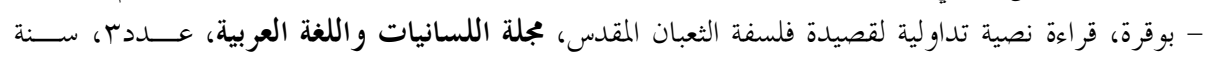

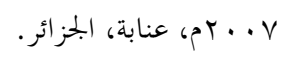

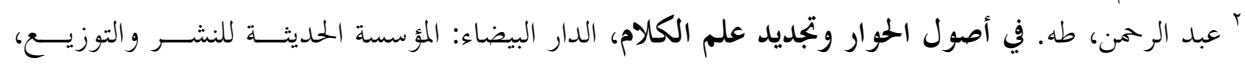

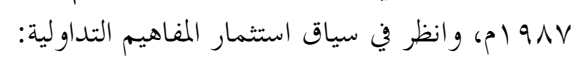

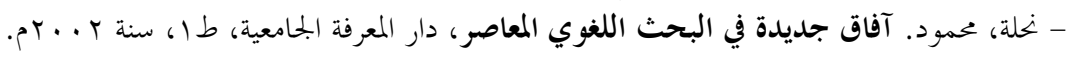

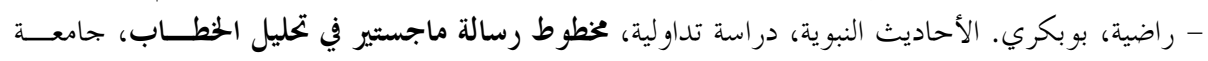

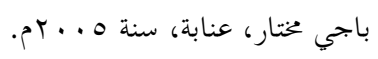

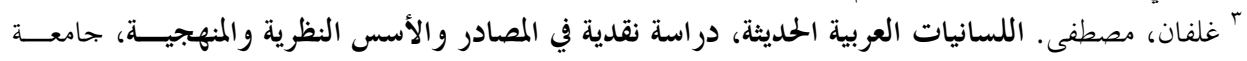

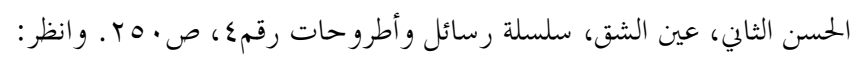

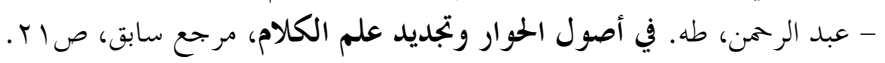




\section{أولاً: تحديد عام لمفهوم التداولية في الفكر اللغوي الحديث}

التداولية ابتحاه فلسفي ولغوي يعنى بدراسة استعمال اللغة في الخطاب، شـــاهدة في ذلك على مقدرةا الخطابية. فهي بذلك تهتم بالمعنى كالدلالية وبعض الأشكال اللسانية التي لا يتحدد معناها إلا من خلال استعماها، ؛ وعدها "فرانسيس جاك "F.jak" -وهو

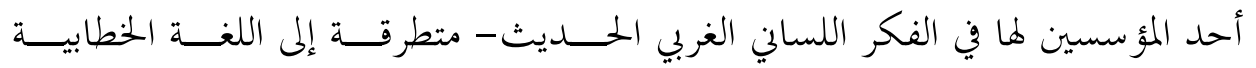

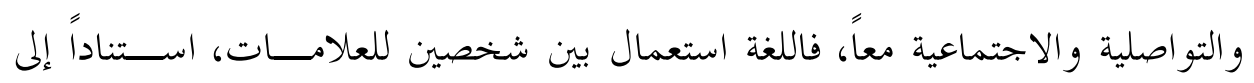
قو اعد موزعة تخضع لشروط إمكانية الخطاب.

وفي الدرس النقدي العربي، يعترضنا تعريف صلاح فضل لها من أها ذلك الفـــرع

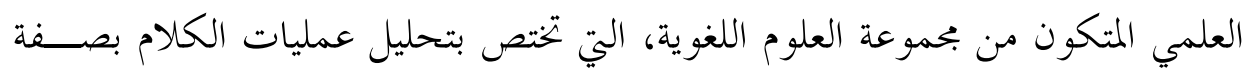
خاصة، وووظائف الأقو ال اللغوية وخصائصها خحلال إجراءات التواصل بشكل عـــام،

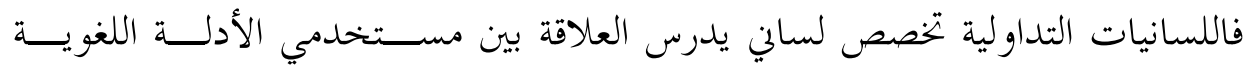
(المرسِل، المرسَل إليه)، وعلاقات التأثر و التأثير بينهما، في ضوء ما ينتجانه من تحـــاور

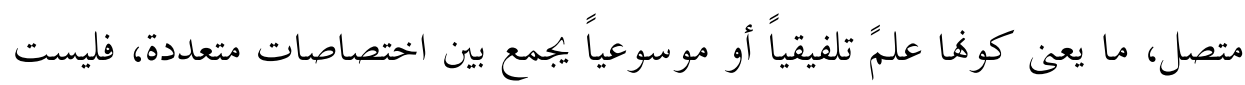

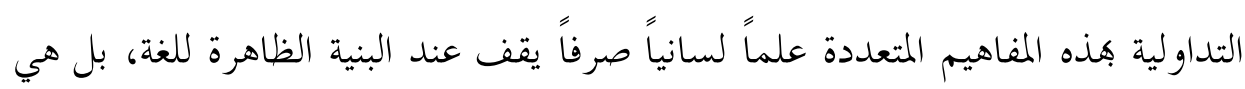

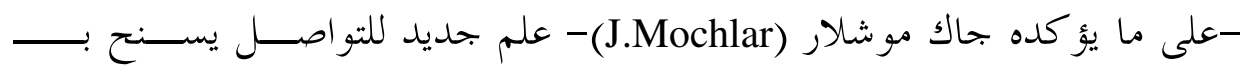

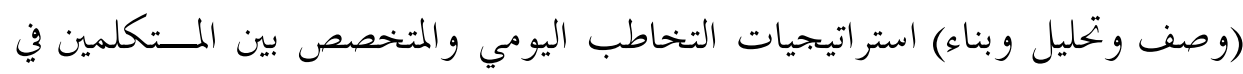
ظروف مختلفة، و وربما تمكنا هنا من اختزال أهم الموضوعات الشائكة التي تعنى التداولية

${ }^{4}$ Froncois Recanati, naissance de la pragmatique, in quand dire c est faire ,p185.

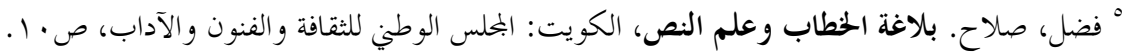

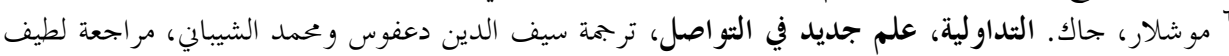

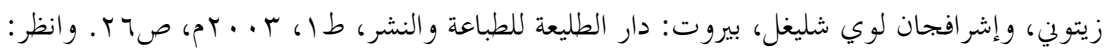

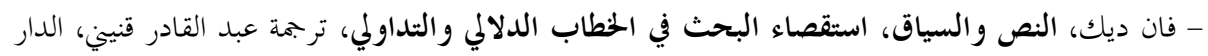


ببحثها وهي ماثلة في: ₹ دراسة بنية الخطاب لغوياً في ضوء قو اعد التخاطـــب العامـــة والخاصة، ووصف علاقة النظام اللغوي بالاستعمال وتحليلــهـه وكيفيــات التحقـــق، و العمليات الذهنية ومستويات الإنتاج و الفهم اللغويين، وفهم مقاصد الخطاب، وأدوار

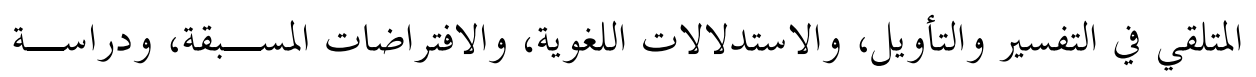
تحول القول إلى فعل كلامي إبحازي في ضوء نظرية أفعال الكلام لأوستن وسيريل. ^ إن اعتماد المنهج التداولي في تحليل نصوص المعارف والعلوم المختلفة، يجد تسويغاً له أنه منهج بحاوز لتلك التحليلات البنيوية و الشكلية، التي تقف عند حدود الوصــف الظاهري لعناصر الملفوظ، غير آبهة بدلالاته السياقية وأغراضه التواصلية التي لأجلـــــا

ل براون، ويول. تحليل الخطاب، ترجمة: محمد لطفي الزليطي، ومنير التريكي، جامعة الملك سعود، مقدمة المؤلفين، وانظر: - سليمان ياقوت، محمود. معاجم الموضوعات في ضو ضوء علم اللغة الحديث، الإسكندرية: دار المعرفة الجامعية، r. ^ يأتي الحديث في هذا السياق عن أوستين (Austin) الذي قام بالرد على فلاسفة الوضعية في محاضراته التي ألقاها

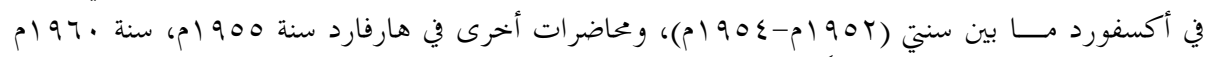

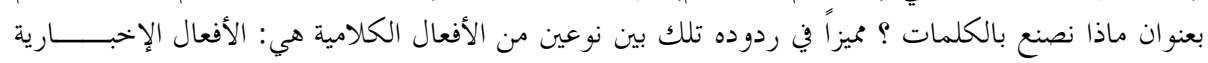

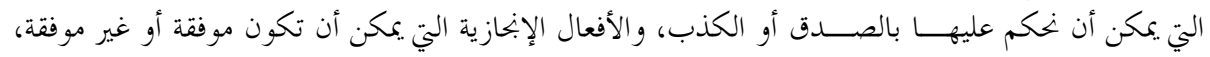

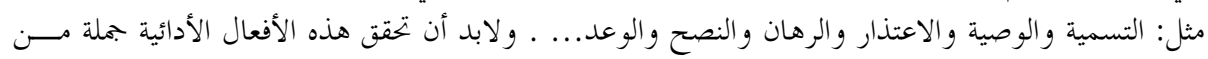

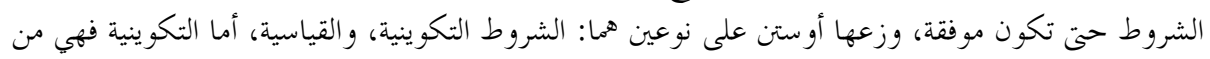

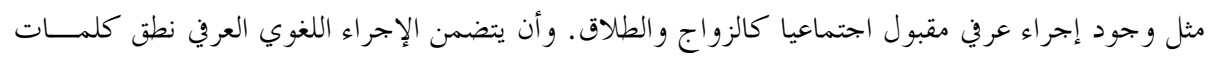

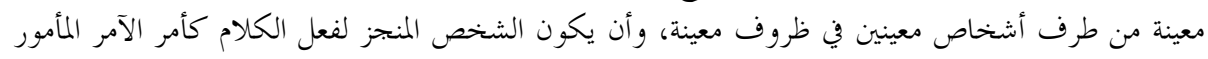

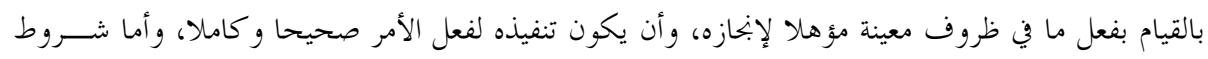

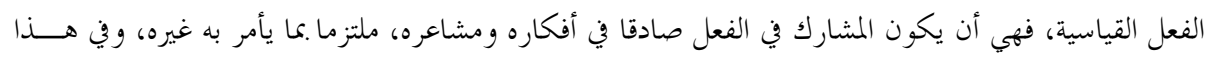

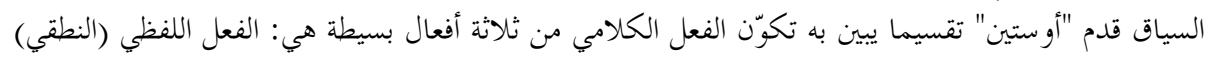

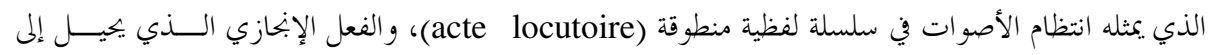

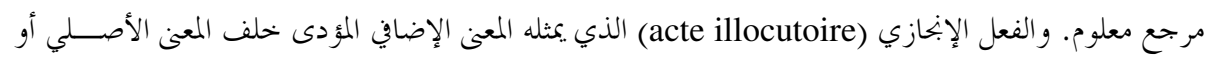

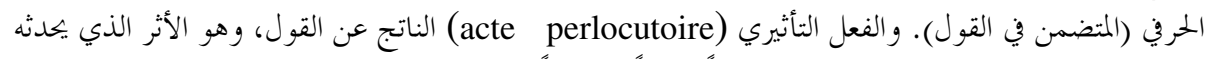

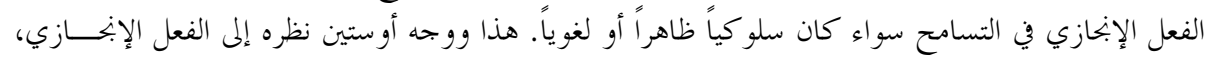

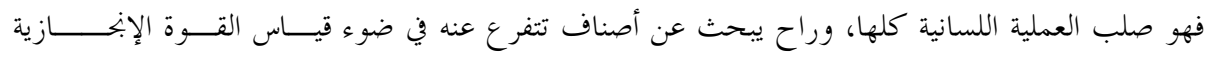
للفعــل المــؤدي (La force illocutoire). 
أنشئ. إن المنهج التداولي بصورته الحلديثة، وشكله التراثي، ينظر إلى اللغـــة بوصــــها

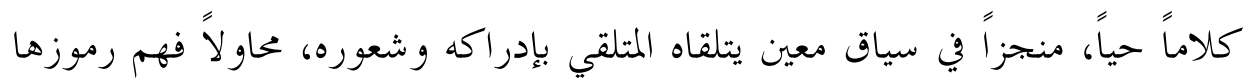
وإشار اتها، وتصريمها وتلميحها، من خلال ما ينتجه الخطاب من آثار سلوكية تنقـلـل الملفوظ من الوجود النطقي إلى الوجود الفعلي، ويتحول فيه المجرد إلى محسوس، وبذهه

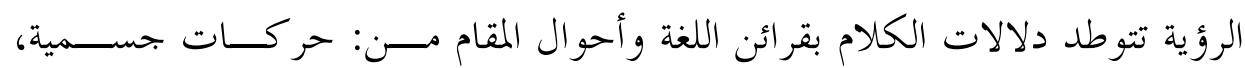

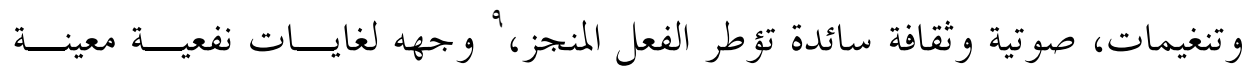
يرتضيها المنجز، ويتقبلها المتلقي. وتتلخص الفلسفة التداولية الحديثة في حقيقة تداولية كبرى، وهي أن لا كلام إلا بين اثنين، حتى ولو كان الكالام حادثاً بين المتكلم وذاته، ولئه و وي هذه الحال ستكون علاقة المتكلم بالمستمع ضمن علاقة العرض للفكرة و المعتـــرض عليها، و لا يكون الاعتر اض إلا بدليل، و لا معترض إلا لطلب الصـــواب، و لا طلـــبـ

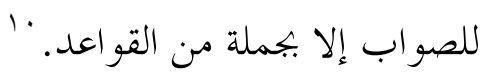

\section{ثانياً: مسارات التفكير التداولي البياني في التراث العربي}

تقف هذه الدراسة عند ثلاثة مسارات مهمة تؤطر البحث في الأبعاد التداولية في

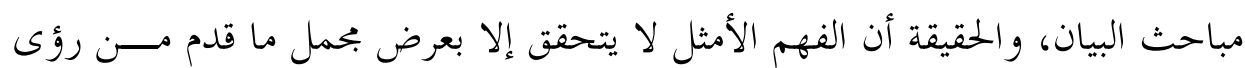

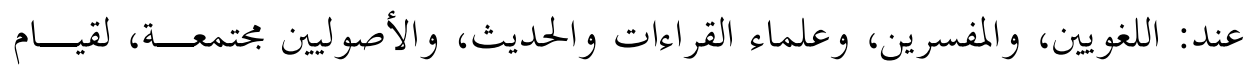

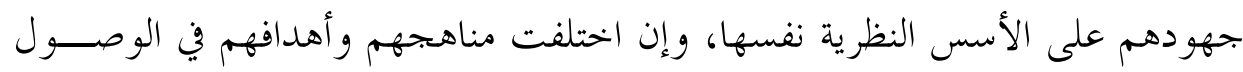
إلى بنية النص وخصائصه البيانية المعجزة.

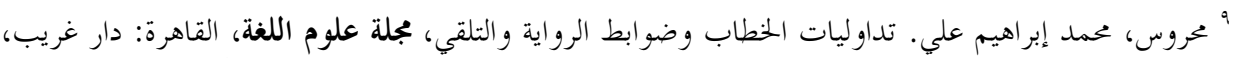

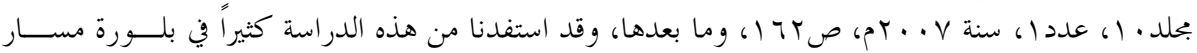




\section{ا ـ المسار اللغوي البيالي:}

يمثل البيان المور الرئيس للنظرية البلاغية؛ إذ استقطب اهتمامه الفكري، وأضحى المعادل الموضوعي لعلاقة اللغة بالمتكلمين في السياقات المعينة، والبيان -عند الجاحظ-

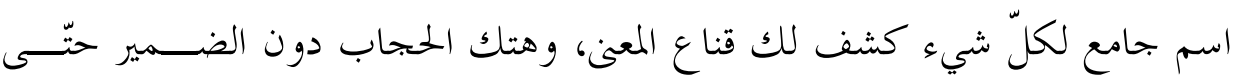

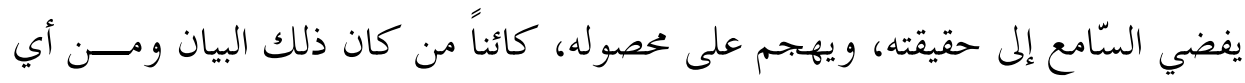

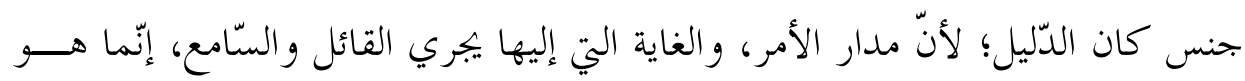
الفهم والإفهام، فبأيّ شيء بلغت الإفهام، وأوضحت عن المعنى، فذلك هو البيــان في

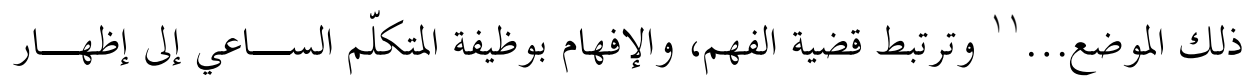
الخفيّة، وتوضيحه للسامع، بالاستعانة بكلّ الوسائل اللسانية والإشارية لتحقيق الفهم.

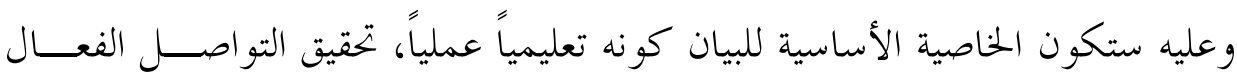

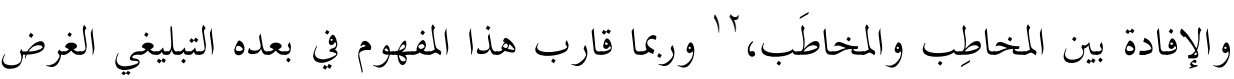
التداولي للخطاب التواصلي في المقامات المختلفة من وجهة نظر حديثة. وفي هذا السياق يذهب الجاحظ إلى ضرورة التركيز على مقصد أدبي مهم، يتمعن في إفهام المخاطب وإبلاغه محتوى الرّسالة الأدبيّة من لدن المرسل، الذي تتعاظم وظائفه

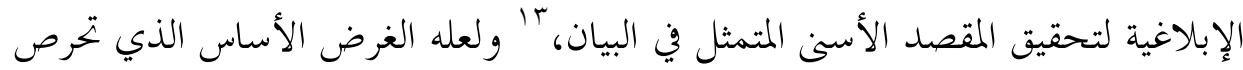
التداولية المعاصرة على تحقيقه في الخطابات المنجزة. ولما كان من المستحيل أن يقتنــع المتلقي .ما هو غامض وغير مفهوم في الخطابات المنجزة والمبلغة، وسعياً إلى إبراز خطر

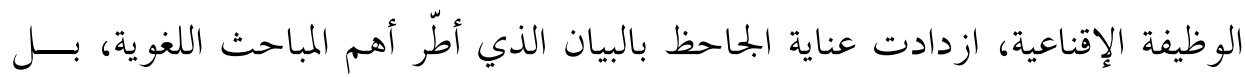

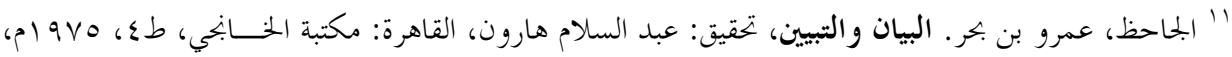
. v /

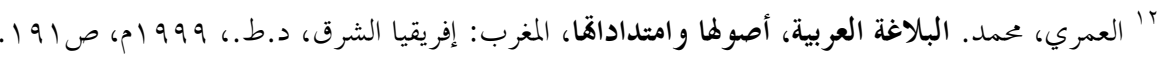

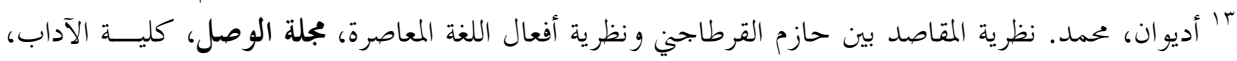


أضحى الموجه المعري لمسألة الوجود من خلال المقولة الشهيرة، التي أحسن الجـــاحظ

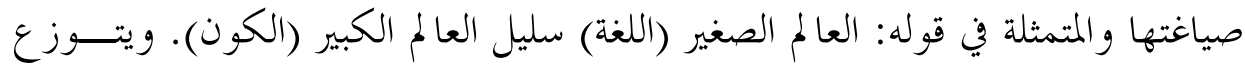

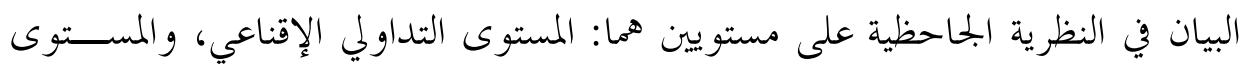

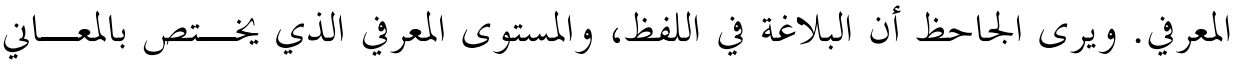

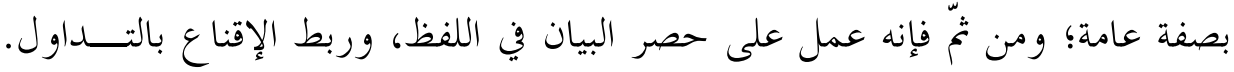

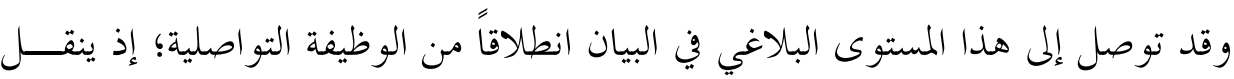

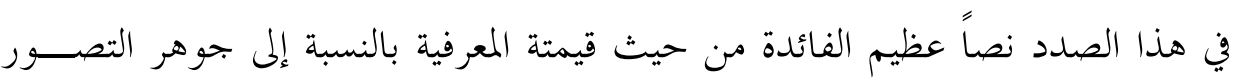

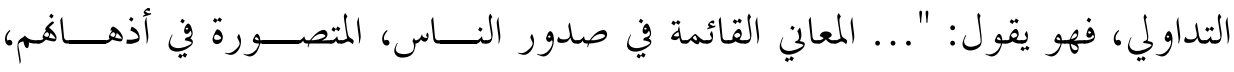

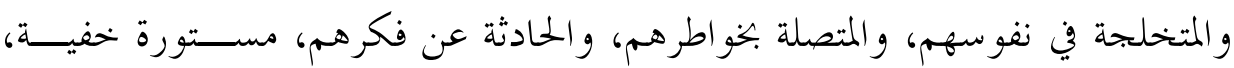
و بعيدة وحشية، ومحوبة مكنونة، وموجودة في معنى معدومة، لا يعسرف الإنســان

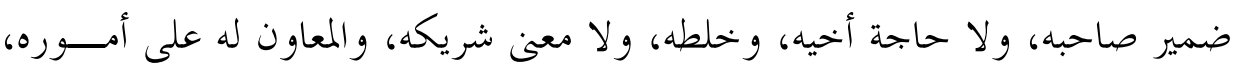

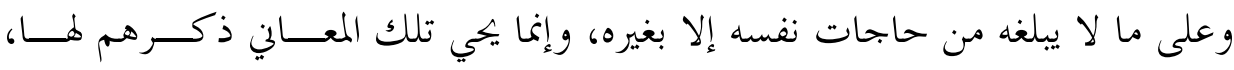

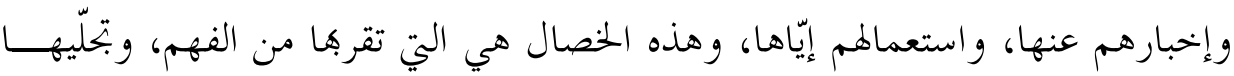

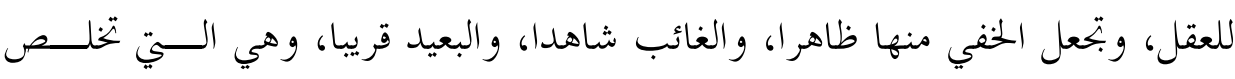

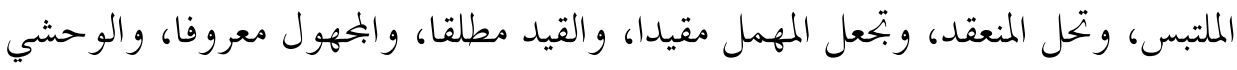

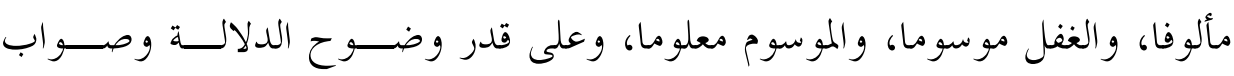

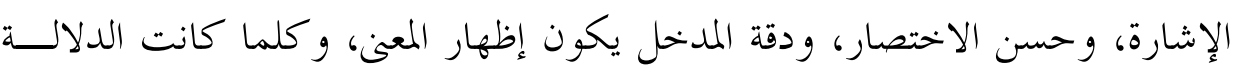

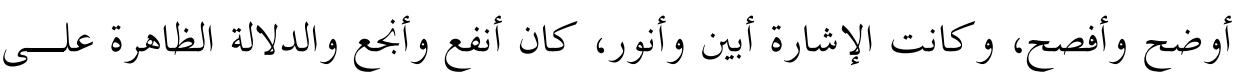

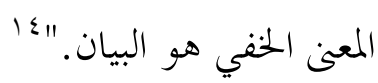

يحيل هذا النص إلى أسس العملية التواصلية بشتى وظائفها في إطار علــــم اللغــة

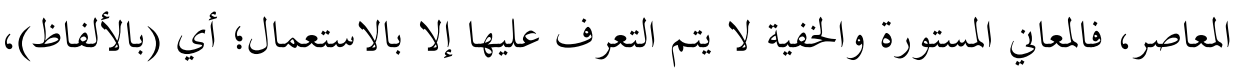


و كذلك بالإخبار عنها؛ أي الإبانة أو البيان الذي أشار إليه في قوله، ويســاير هــــا

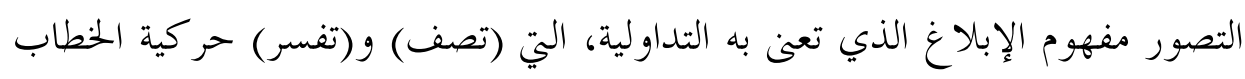

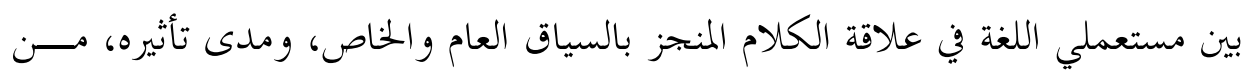
حيث هو سلسلة من الأفعال في المتلقي في مستوى الفهم والفائدة، وهذا ما ذهب في إليه

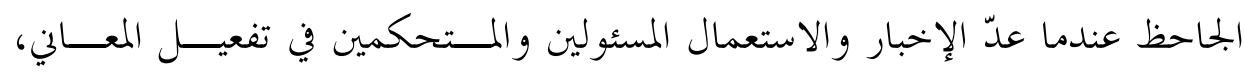
وإعطائها وظائف لسانية و بلاغية وإقناعية معينة.

كما بحلت ملامح التداولية بشكل أكبر عند السكاكي من خلال توصيف عناصر

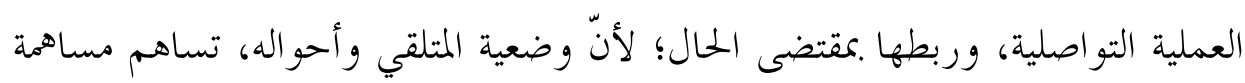

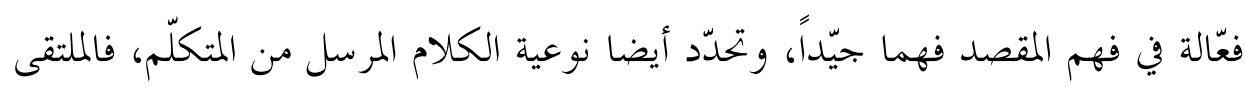

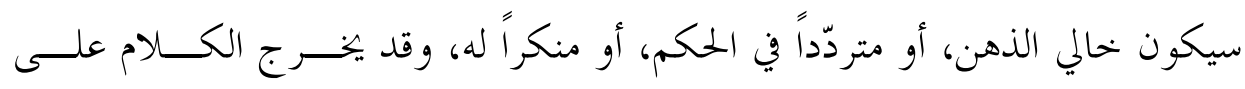

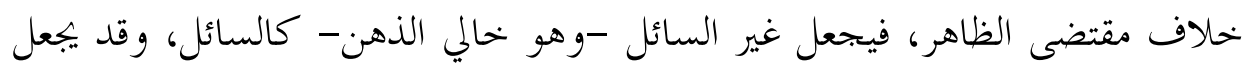
غير المنكر كالمنكر، وقد يجعل المنكر كغير المنكر.

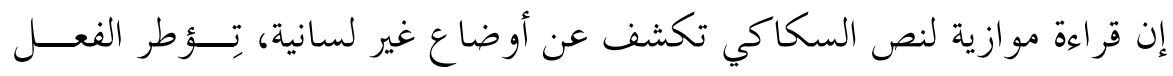

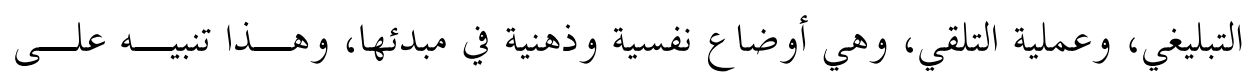

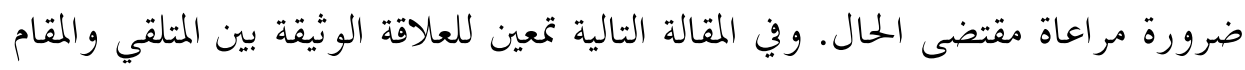

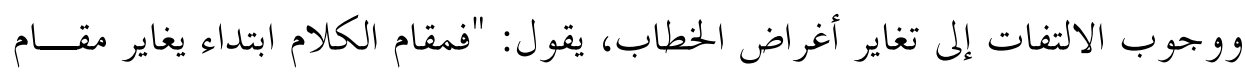

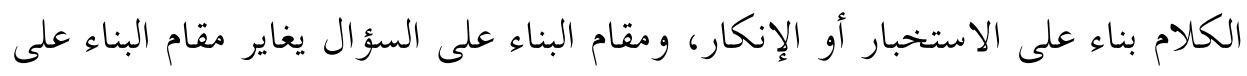

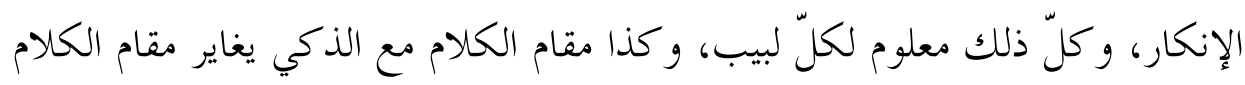

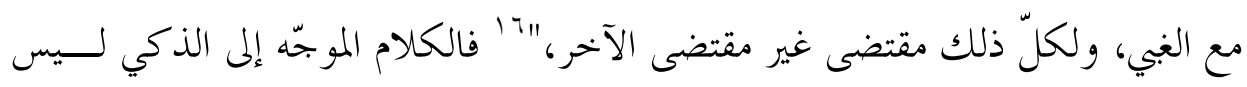

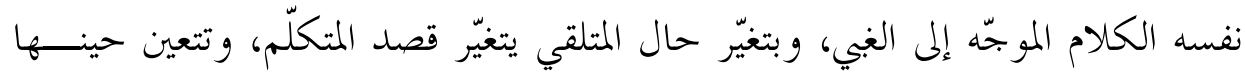

$$
\text { "10 المرجعاكي، أبو يعقوب. مفتاح العلوم، بيروت: دار الكتب العلمية، د.ت.، ص.V. }
$$


مقصدية الإفهام واستجابة المتلقي.كما تتمركز نظرية الأفعال الكلامية في بؤرة اهتمامه

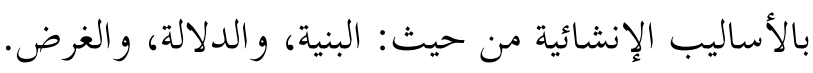

ولأنّ بلاغته بتحمع بين النحو، والمنطق، والشعر، عدّ السكاكي أنموذجهـاً عربيــاً

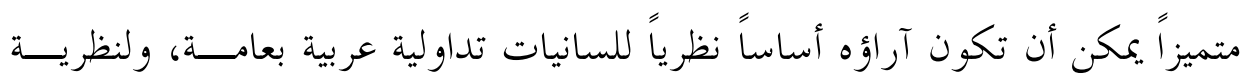

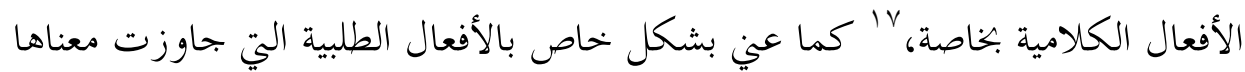

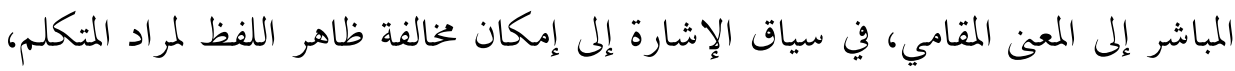

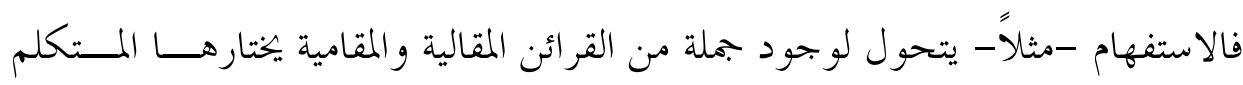

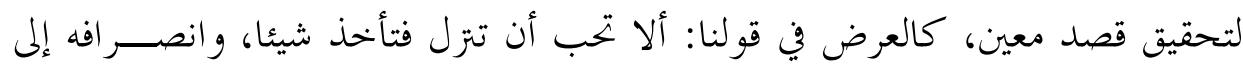

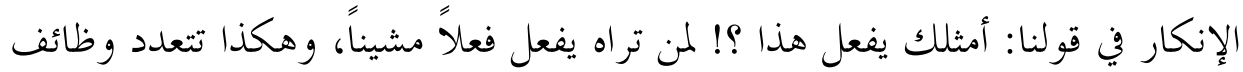

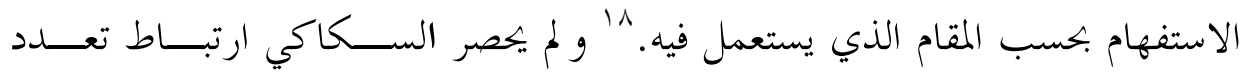

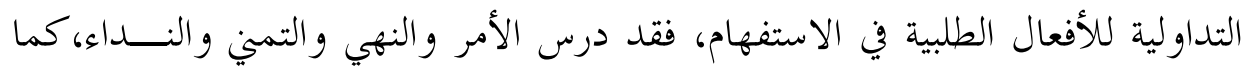

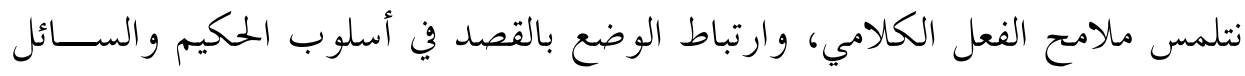

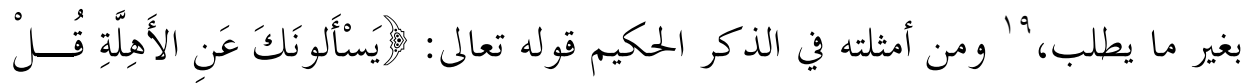

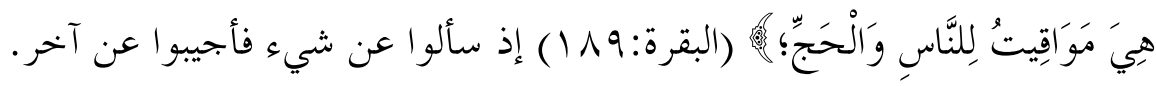
أما ابن خلدون فقد صاغت رؤيته البيانية -فيما نزعم- آراء سابقيه، ولعله يكون

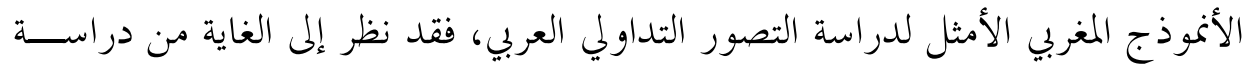

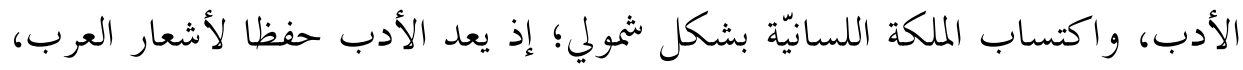

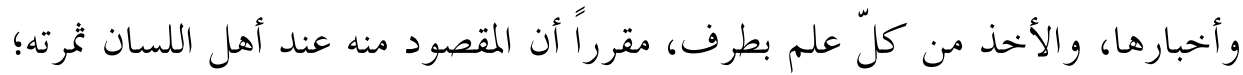

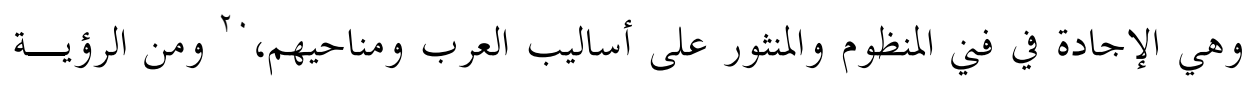

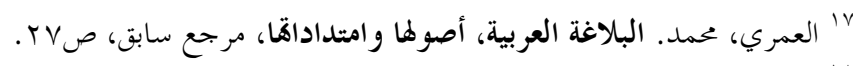

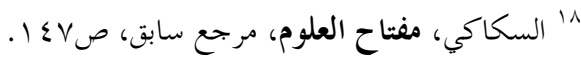

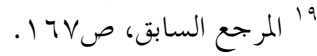

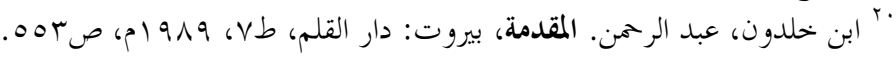




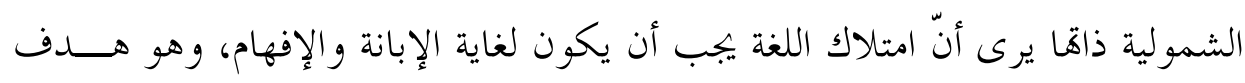

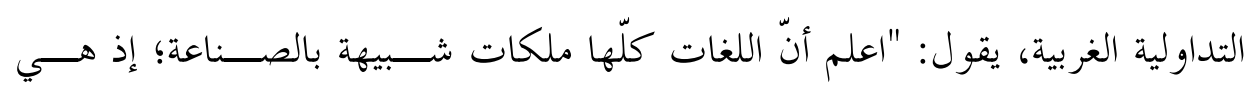

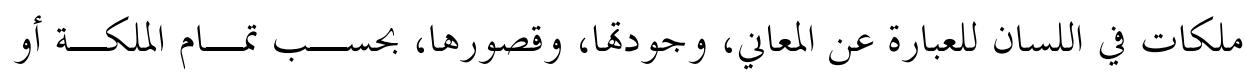

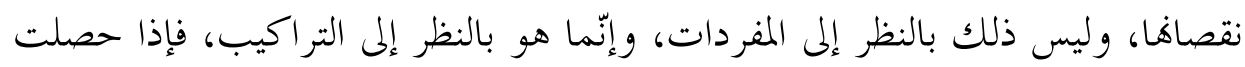

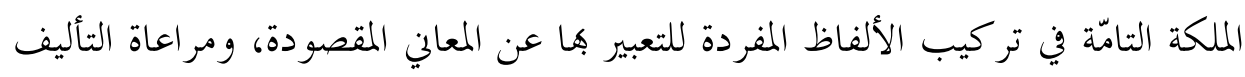

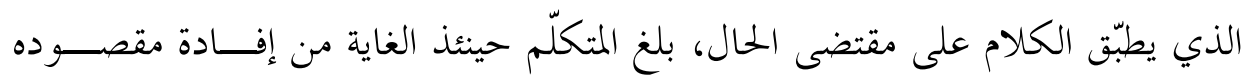

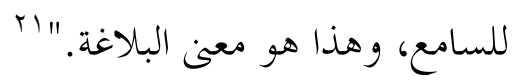
أما عن أهم ما ورد في هذا النص الخلدو ين من مقولات تداولية، فيمكن صــياغته

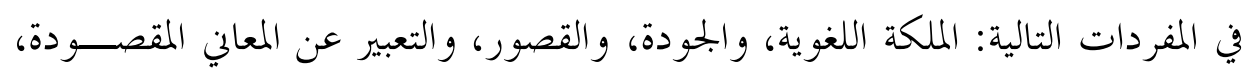

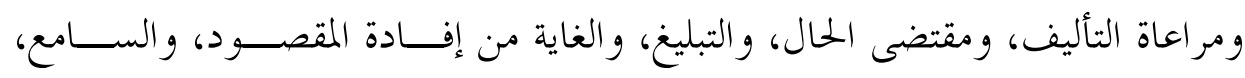

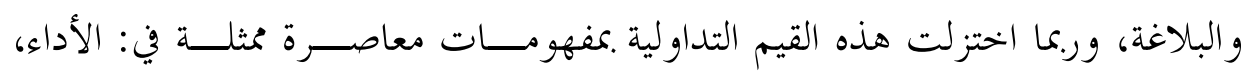
الكفاءة، القصد، التركيب، السياق، المتلقي، الإبلاغية، وغيرها.

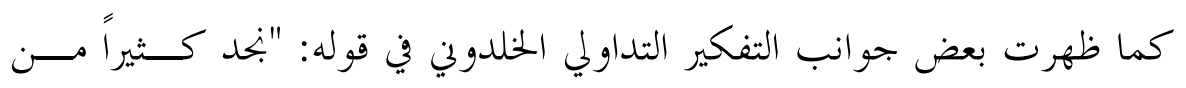

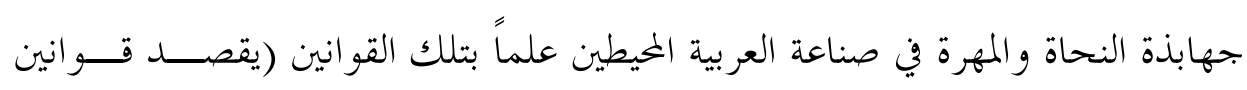

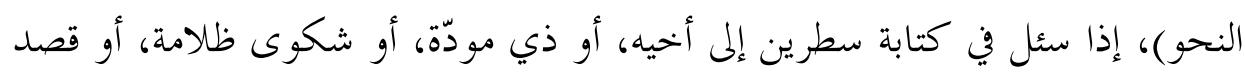

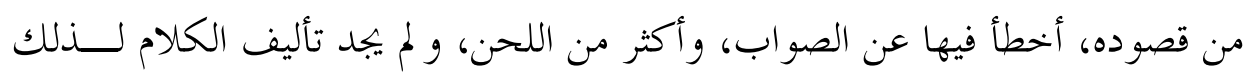

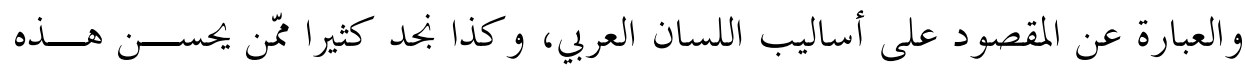

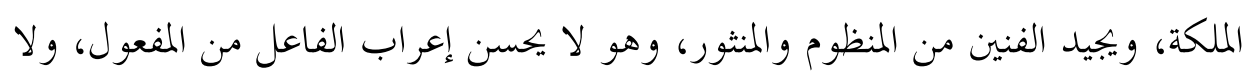

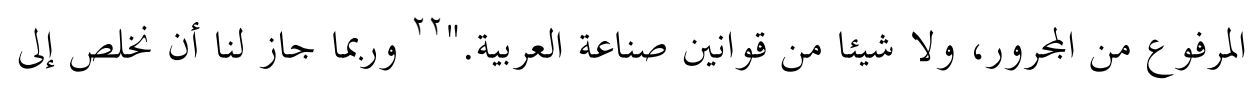

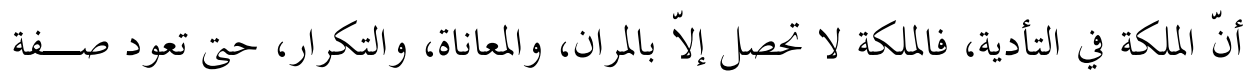

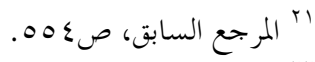

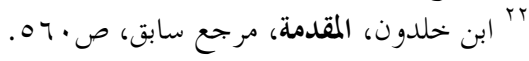




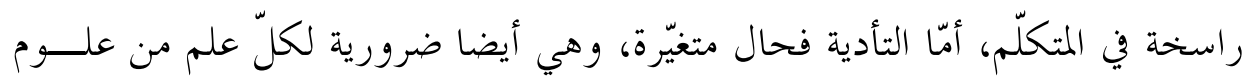

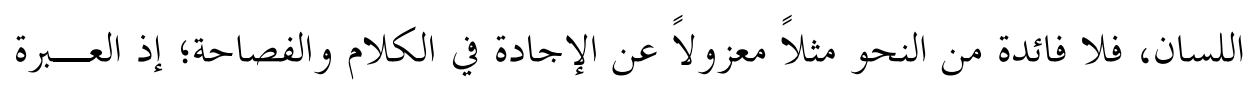

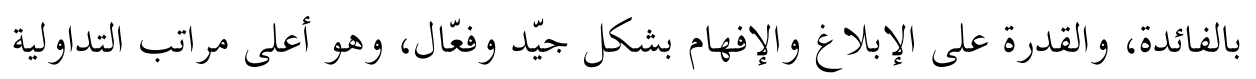

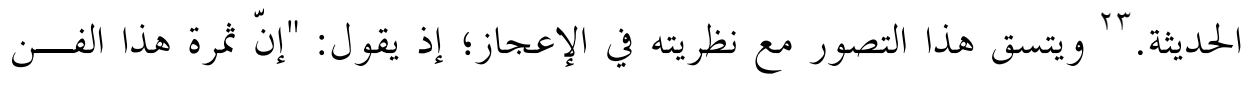

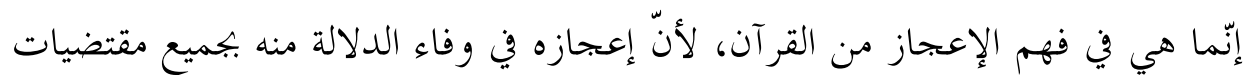

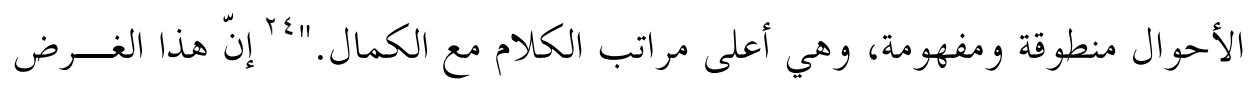

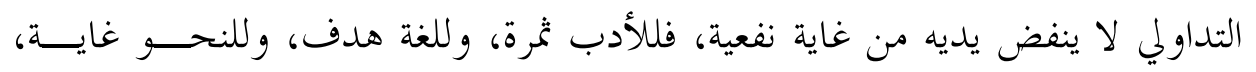

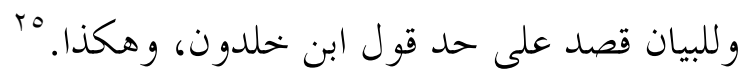

أما حازم القرطاجين، فنتلمس تصوره التداولي من خلال ثلة من النصوص لعَّل

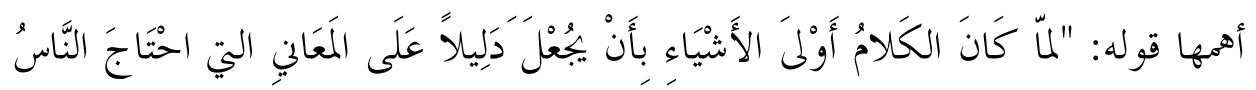

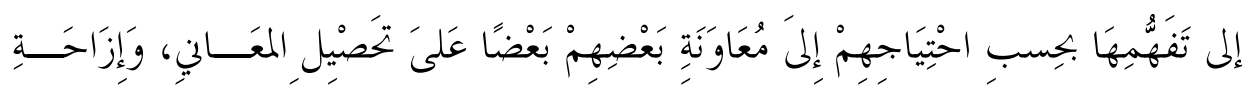

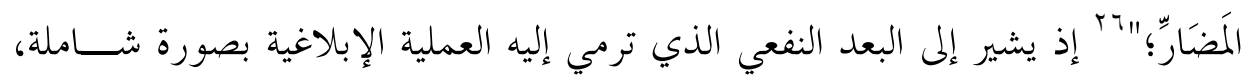

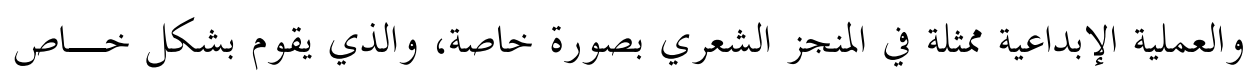

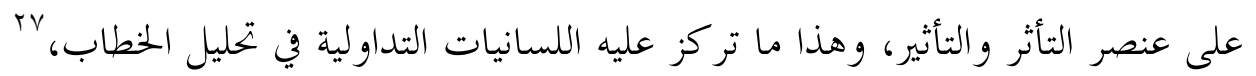

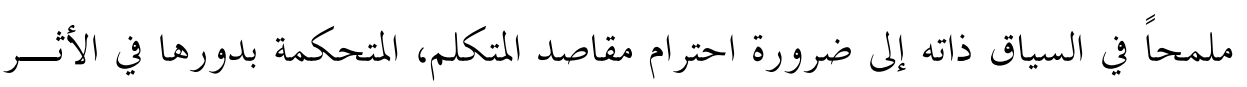

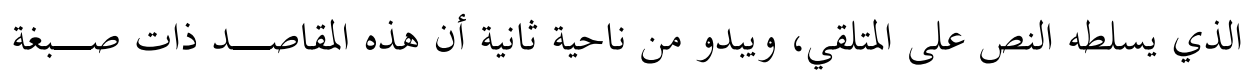

rT علوي، سالم. ابن خلدون وعلوم اللسان العربي، مجلة اللغة والأدب، قسم اللغة العربية، جامعة الجزائر المركزية،

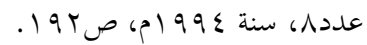

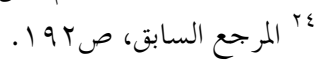

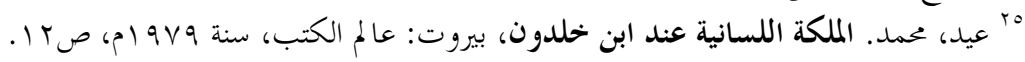

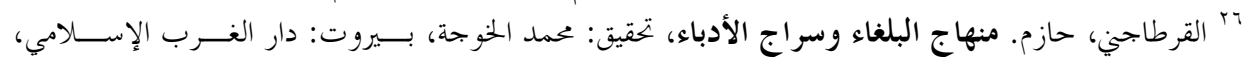

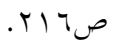
YY أديوان، محمد. نظرية المقاصد بين حازم القرطاجني ونظرية الأفعال اللغوية المعاصرة، مرجع سابق، صجr r. 
حالية تقر أ قراءة سياقية، وهي من ثَمَّم جزء لا يتجزأ من المقام الذي يحتل في التصــور التداولي الحازمي مكانة متميزة.

\section{Y. مسار المفسرين وعلماء الدراسات القر آنية والنبوية:}

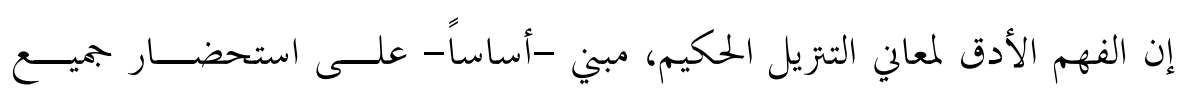

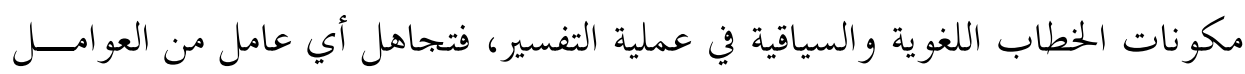

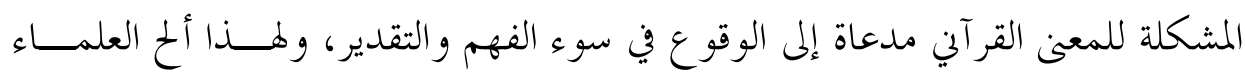

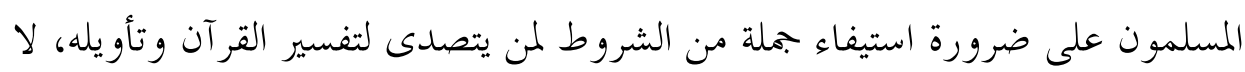

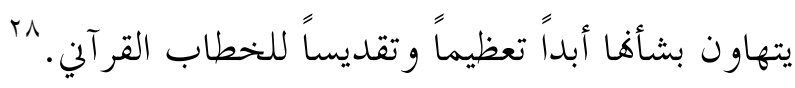
إن تلقي القرآن الكريم بوصفه مستوى أرقى من مستويات الإنحاز الكلامي الذي تحدي به العرب في فصاحتهم وبياهم، يقتضي العناية بالجموانب الصوتية، والصــــية،

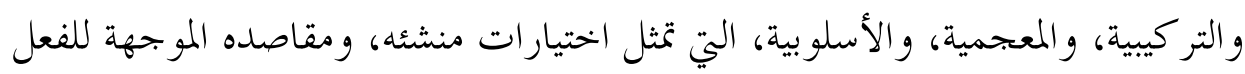

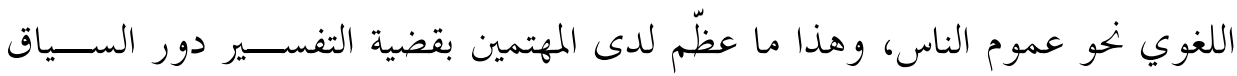

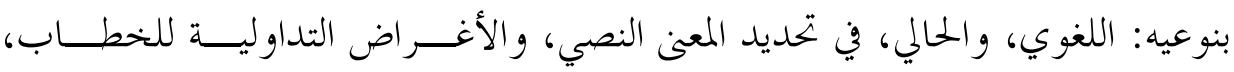

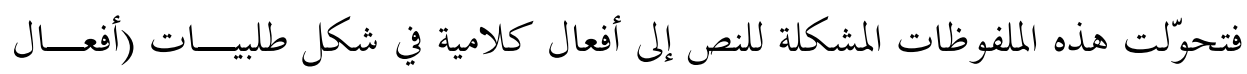
الأمر و النهي)، وسلو كيات (الأخلاق)، وإخباريات (القصص)، وحكميات (أحكــام الجزاء والعقاب)، وتعهديات (الترغيب والترهيب).

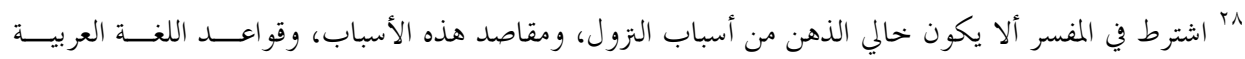

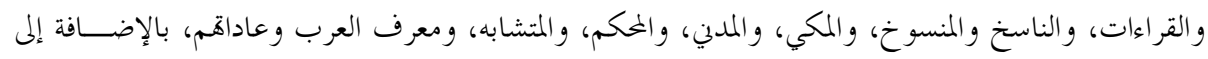

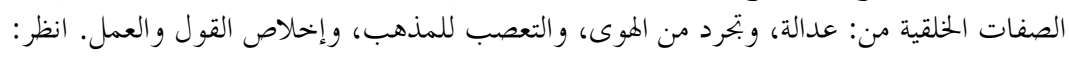

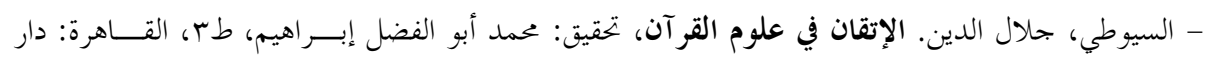

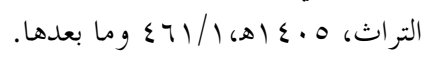


إن كلّ سورة تنهض على ملفوظات وأفعال قولية تحقق بدورها أفعالا كلامية لها بُعد تأثيري على المتلقي، جا توجه أفعاله، و تعدل في سلو كه، وقيمه، ومعتقداته. فتلقّي آيات الرحمة، والعذاب، و الأحكام الشرعية، والإخبار بالغيـــب، و الـــــعوة إلى فعــل الخيرات، وبتحنب المحرمات، كلها موضوعات تدور في فلك الفعل الإبخــــازي الطلـبـي الكلي بشتى أغراضه وسياقاته وشروط تحققه، و التي توجهنا إليها تداوليات الخططـاب القر آني، ومقاصده الكبرى.

إن تلقي القرآن في ضوء العلم بقواعد التفسير، يضمن الحد الأدلى مـــن الفهـــم

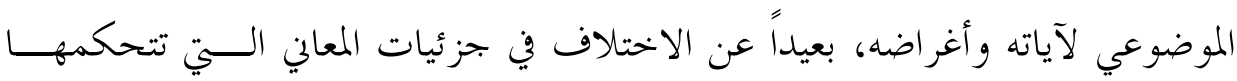
اختلافات في المعرفة الخلفية للمفسر أو المتلقي. بيد أن هذا الإطار، لا يجب أن يلــهي عن ضرورة الاسترفاد من واقع البنية اللغوية في تعلقها بثقافة العصر التي نزل في سياقها القرآن محاولاً تغييرها، وهذا من شأنه أن يكبح جماح توقعات المفسر التي تشدّه قناعاته

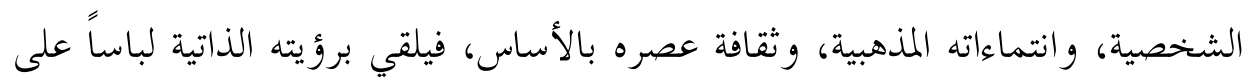

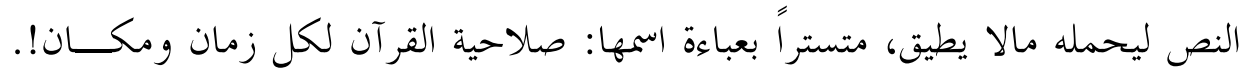
ففي التاريخ الثقافي العربي تفاسير كثيرة عرج بها أصحاها على مذاهبهم، فخرجوا عن

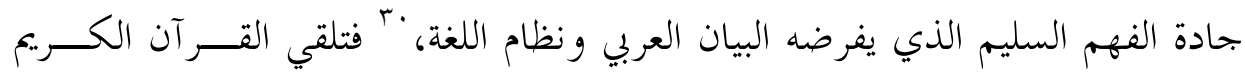
وفهمه، و الوصول إلى مقاصده، لا يمكن أن يتحقق في غياب تلك الشـــروط ســـالفة الذكر، التي هي في الحقيقة قو اعد لتداوليات الخطاب القر آني إنتاجاً وفهماً.

ج"rq صحراوي، مسعود. الثداولية عند العلماء العرب، دراسة تداولية لظاهرة الأفعال الكلامية في التراث اللســاني

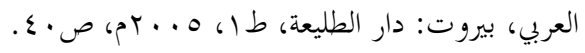

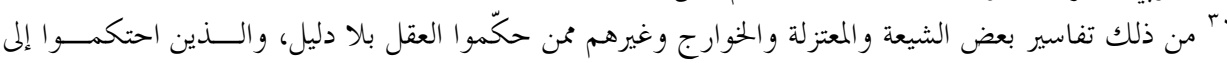

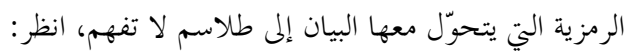

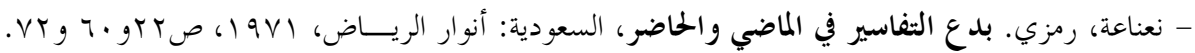

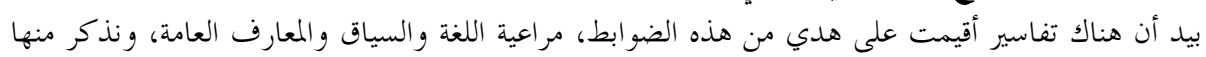

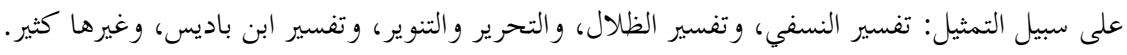




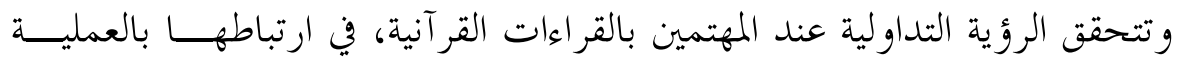

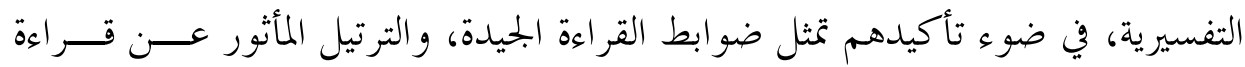

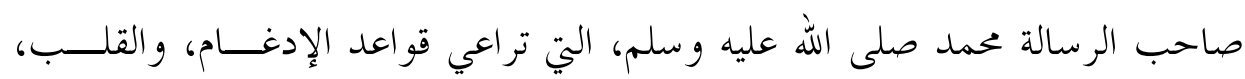
و الإخفاء، و التفخيم، والترقيق، والإمالة، والإشمام، إلخ، وما إلى ذلك من صــور الأداء وهيئته العملية التي تترك أثرا متعدد الأبعاد في السامع الذي تتيح له إمكاناته اللســانية و الجمالية والذوقية التفاعل مع معاني النص، وأغراضه التواصلية، علما أن ذلك التفاعل

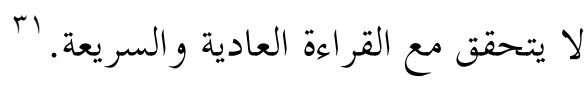

ولا نغادر هذا المسار، حتى نشير إلى أهمية تلك الشروط الــتي صــــــاغها علمــــاء الحديث في طرق الأخذ، و التحمل، ونقل الحديث الأصلية والفرعية منها، للتدليل على تلك الدقة التي تكشف تلقي الحديث، فتميزه من حيث الصحة و الضعف، وما ذاك إلا إعلاء لمكانة القائل الأول، وسمو بالحديث المنقول. و مما يستشف من هذه التصورات، أن عملية التلقي قائمة على أهم ركائز التداولية في اللسانيات الحمديثة، مـــن خــلال

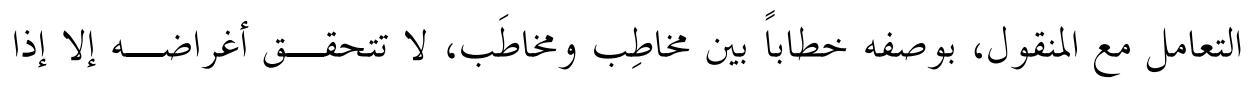
اكتملت شرو ط الصحة و السلامة والأهلية.

ولعل عناية نقلة الحديث بمقتضيات الحديث ومستلزماته، دليل آخر على الاحتفاء بالبعد التداولي للخطاب النبوي، ومن ذلك -مثلا- العناية بنقل الإشارات والحركات الجحسمية المصاحبة لآراء الحلديث وفعل القول النبوي ووصفها، و الحرص على وصسـف

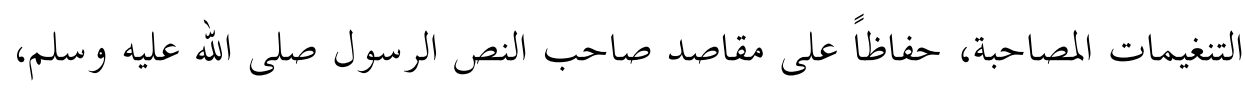

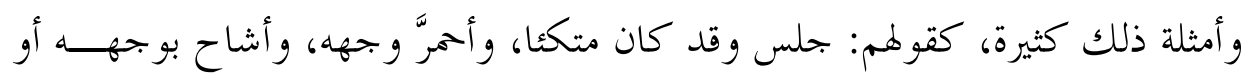

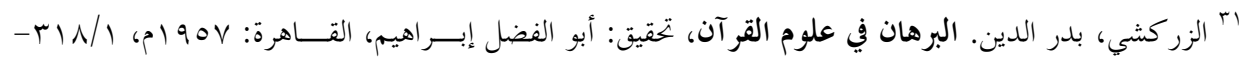
م

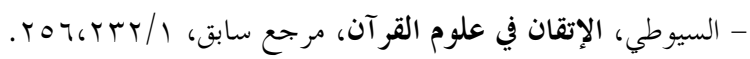


شبك أصابعه، أو أشار بأصبعيه، إلخ، وفي هذا السياق يمكن الاستئناس بما أورده علماء الخطاب في عصرنا، حول دور الإشارات الجسدية والتغيم في مثل قولنا: إني في الحقيقة

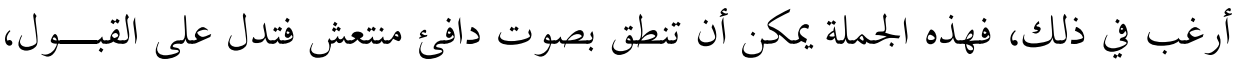

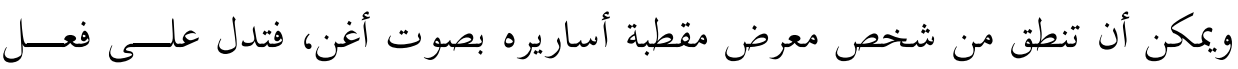

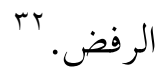

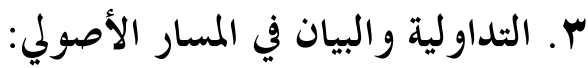

يرى كثير من المعاصرين أن موضوع السياق أو المقام كما عرفه العرب القـــدماء

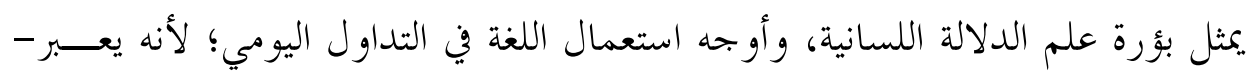

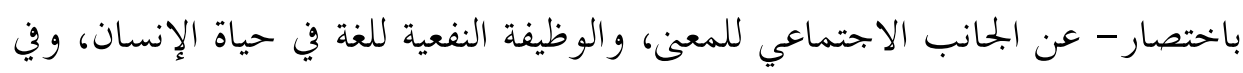

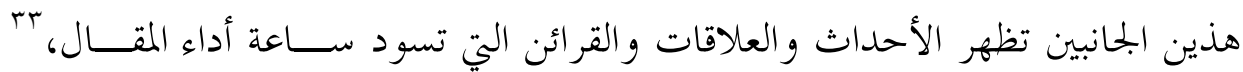

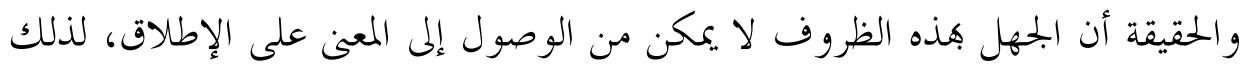

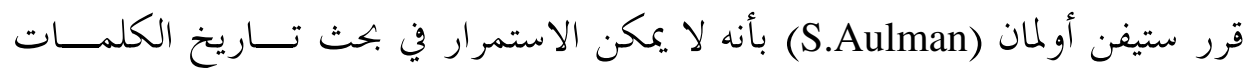

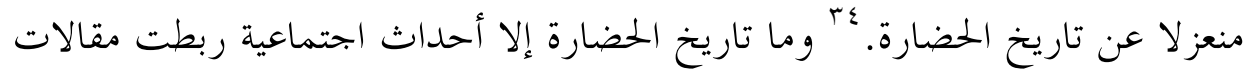

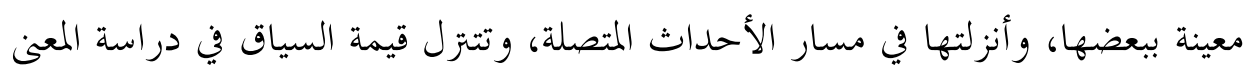

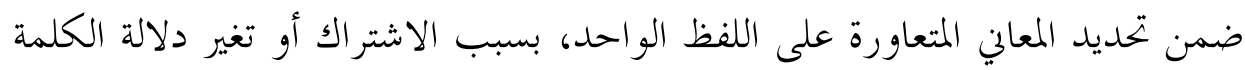

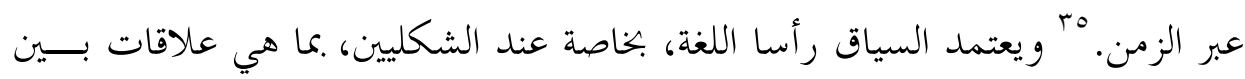

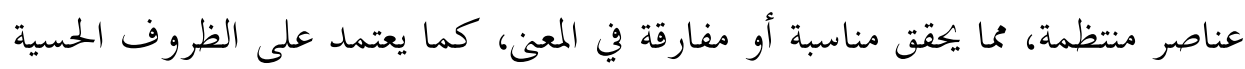

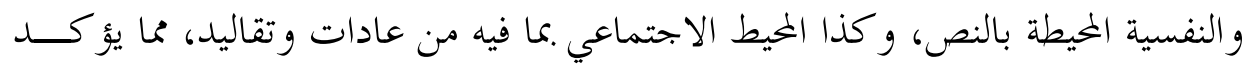

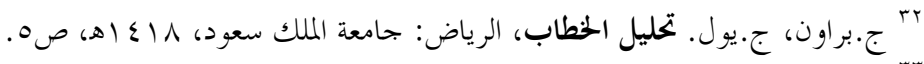

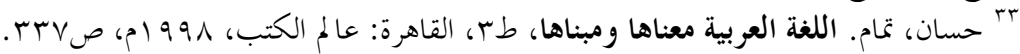

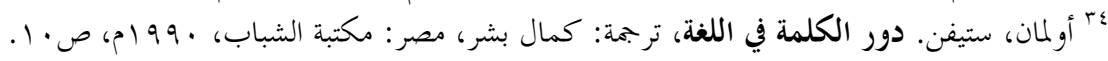

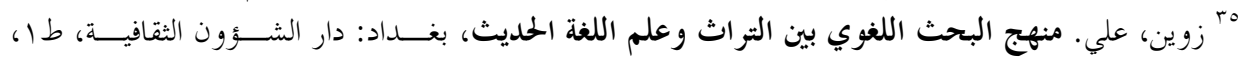


على ضرورة المعرفة التامة بأسباب التزول، وأخبار العرب وحياهم العقلية والروحيـــة و الاجتماعية بصفة عامة. وهكذا، تمتد قرينة السياق على مساحة و اسعة من الركـــائز تبدأ باللغة، وتنتهي هذذه القر ائن المتعددة.

ويمثل باب البيان -عند علماء الشريعة- موضوعاً بالغ الأهمية في تفسير النصوص

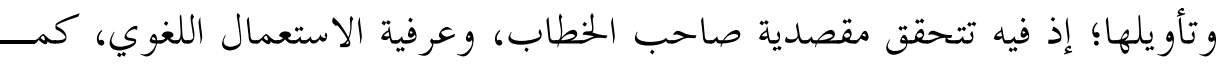

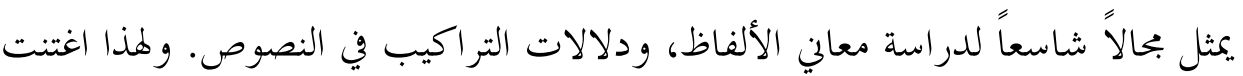

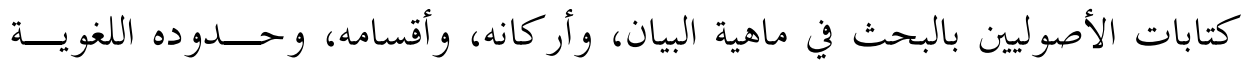

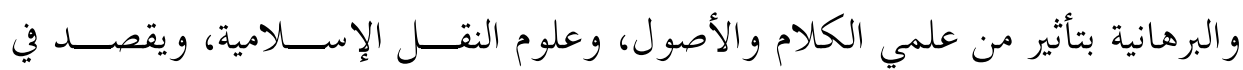
المتعارف عليه إظهار المقصود بأبلغ لفظ، وهو من الفهم وذكــــاء القلـــب، وأصــله

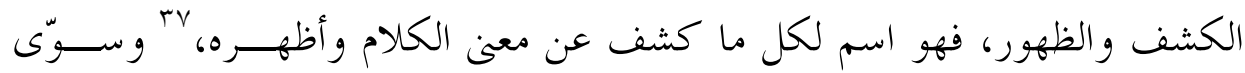
التهانوي بينه و بين الفصاحة؛ إذ يقال: فلان ذو بيان أي فصيح، وهذا أبين من فــلان

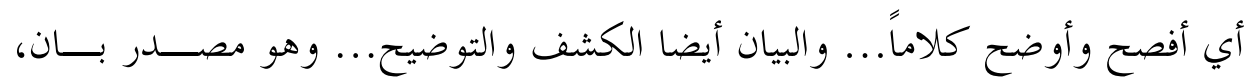

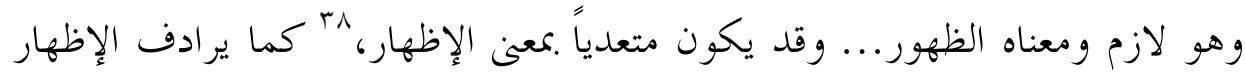

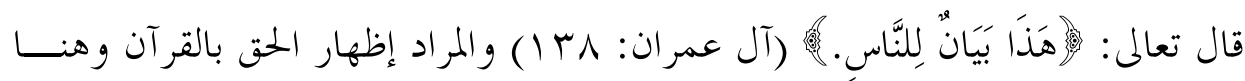
يتجلى جيداً الفعل الكلامي الإبحازي الممثل في وظيفة النبوة المرسلة بالتعاليم الإلهية إلى إلى

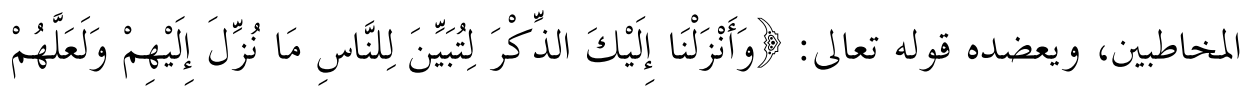

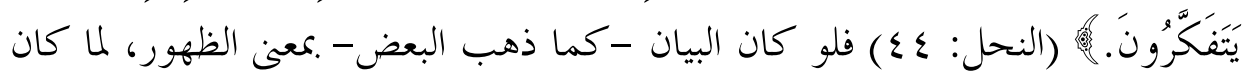
محمد صلى الله عليه وسلم مؤدياً لو اجب الرسالة في حق كل الن الناس.

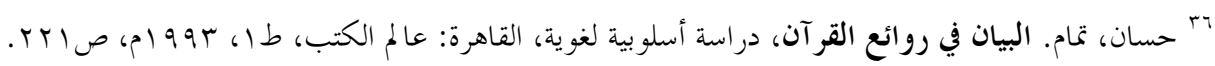

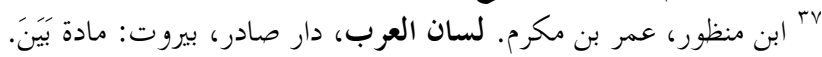

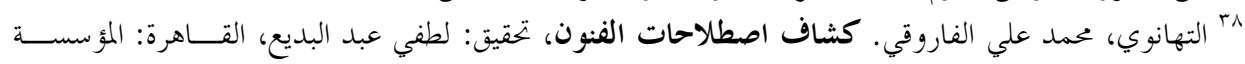

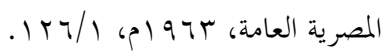

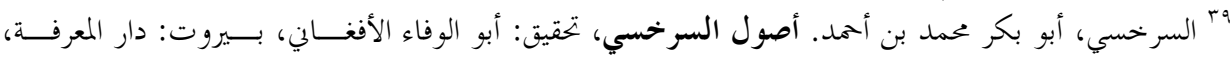


و البيان عند الأصوليين - في الأصل - هو مادة الدليل الموصل إلى الحلكم الشرعي،

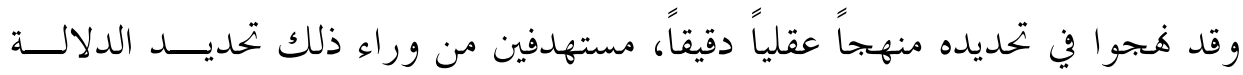
النصية، •؛ ولعل اجتهادهم في تحديد أنواعه أبرز دليل على عنايتهم به، وسنكتفي بذكر

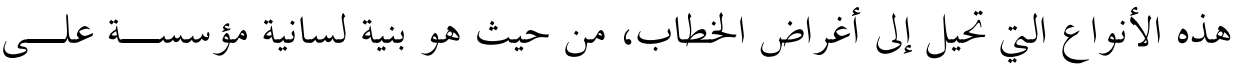
عرف لغوي خاص وقصدية معينة تحققها جملة من الأساليب الإنشائية الطلبية، كالأمر و النهي، وما يكيلان عليه من دلالات دون الإيغال في تحليلها، حتى لا نخرج عن الخــــ الذي رسمناه لأنفسنا بعدم إغفال النقطة الجموهرية في الموضوع، وهي التركيز على محل

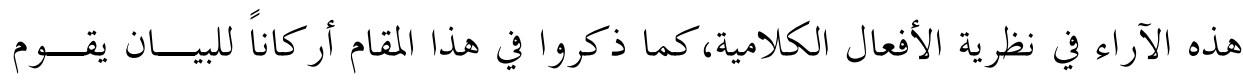
عليها، وهي المبيُِّ (الله عز و جل) أو الرسول صلى الله عليه وسلم، و البيـــان، ويمثــلـل الدليل الموصل إلى معرفة الحلكم، أما اللفظ الذي تتضح دلالته بحيث يعرف المراد منه،

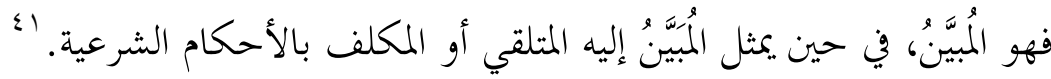
إن هذا التصور - كما هو واضح- يبين إدراكاً عميقاً لحقيقة العملية التبليغية مــن

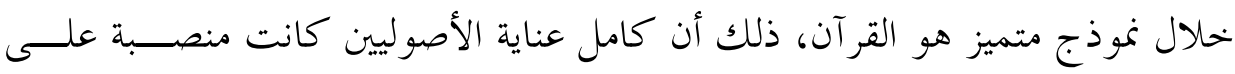
إبراز خصوصيات الإعجاز النصي، وكيفية تلقي المكلفين للآيات القرآنية، بوصسـفها

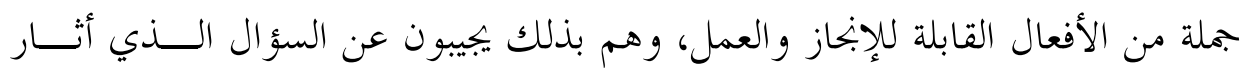
المحدثين حول كيفية تحويل القول اللساني إلى فعل منجز حقيقة. وفي سياق تعاضد الخطابات، أو ما يمكن أن يعد نصوصاً موازية تسهم في التلقي المنتج، بوصفها سياقات معرفية ولغوية، يشير ابن حزم إلى ضرورة التوقف مع مصادر التشريع جملة واحدة، لفهم أغر اض الخطاب الديني القرآي ومقاصده؛ فالقر آن مصــــر المصادر كلها في نظرية الفقه والاستنباط، وما من أصل شرعي إلا كان اشتقاقه منــه،

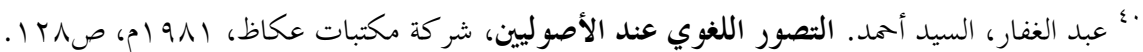

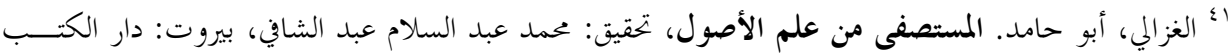


وهو الذي ثبتت به الرسالة المحمدية، بوصفه المعجزة الإلهية المؤيدة للنبـــوة، كمـــــأن أن

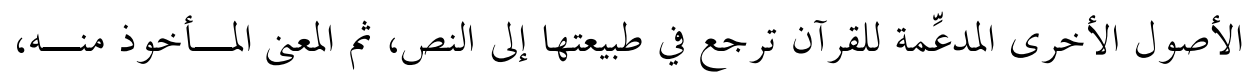

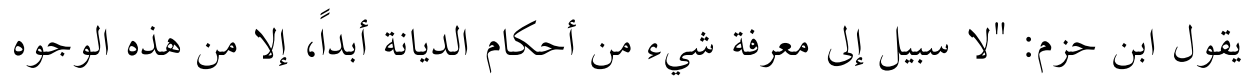

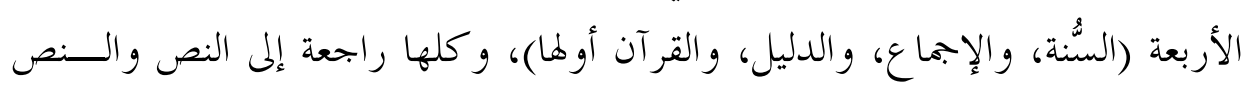

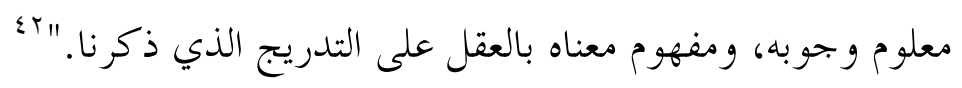

وفي سياق التأكيد على ضرورة إدراك المقام لفهم خصوصيات المقـــال، نســوق النص التالي توضيحا لذلك، يقول ابن حزم: ". .. و البيان يختلف في الوضوح، فيكون ليان

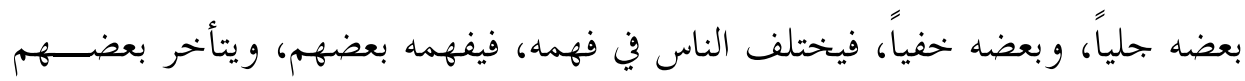

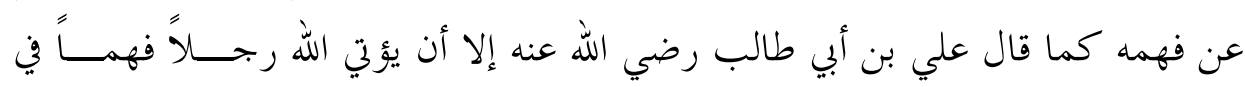
دينه، و كما تعذر على عمر رضي الله عنه -وهو الغاية في العلم بنص البي صـــلى الله

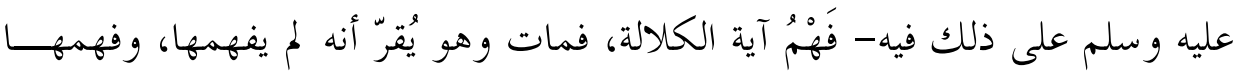

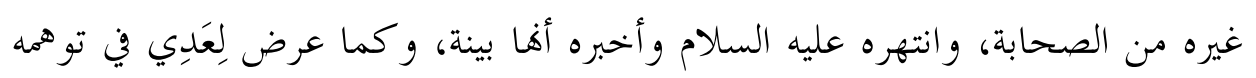

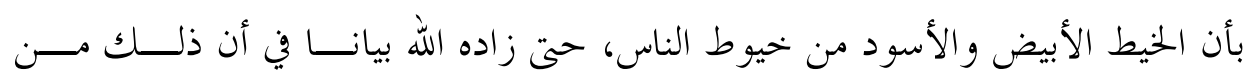

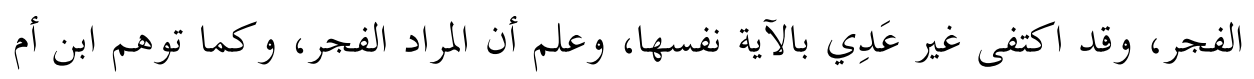

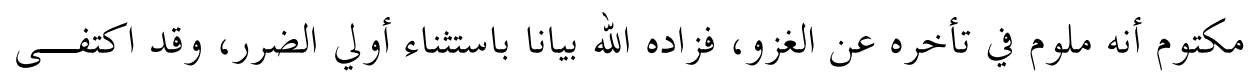

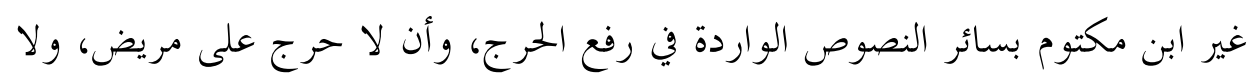

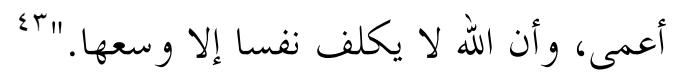

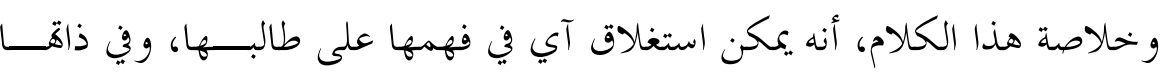

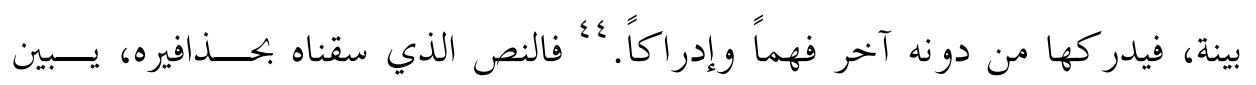
ضرورة العناية بالسياق العام للخطاب، وتتجلى عناية المقاربة الأصولية بقصد المخاطب فئب

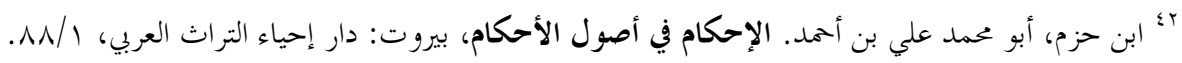

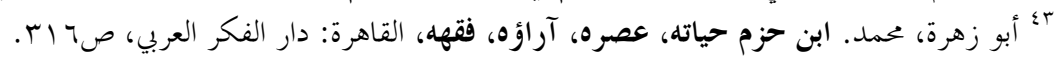

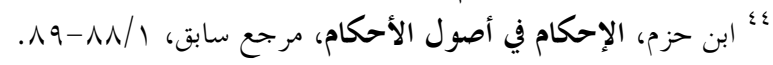


في مباحث البيان، من خلال التمييز بين الاستثناء والتخصــيص؛ فالاســتثناء بيــان وتخصيص في الآن معاً، ذلك أنه تكلم بالباقي بعد أداة الاستثناء، كما يتضمن في ذاته

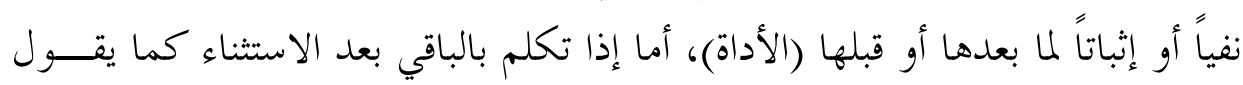
علماء اللغة، فهو ليس من التخصيص؛ لأن التخصيص معناه أن يكون اللفظ في ذاتــهـ

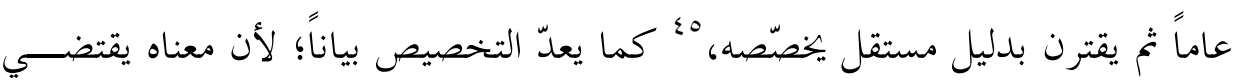
بيان العام الذي لا يراد به ما يدل عليه اللفظ، بل يراد به أول الأمر الخاص، فلا يكون

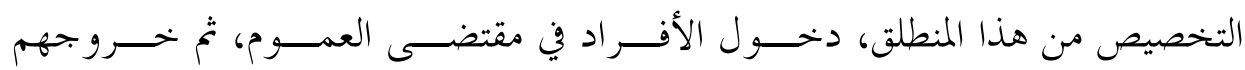
بالتخصيص، بل المقصود أن اللفظ العام أريد به بعض أفراده من أول الأمر. بـ

أما الكناية بالإشارة، فإن الإشارة تعود على أبعد مـــــور، إذا كانـــت ألفاظـــا خصوصة يحددها النحاة بذلك، وتلك، وهو، أولئك، وهم، وهي، و هما. أما إذا كانت بألفاظ كهذا وهذه، فإنها (الإشارة) راجعة إلى أقرب مذكور. وثمرة هـــذا الوصــف

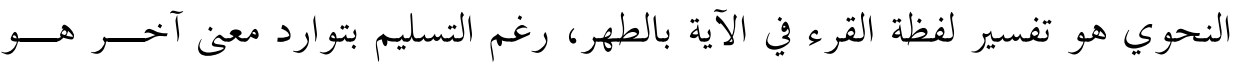

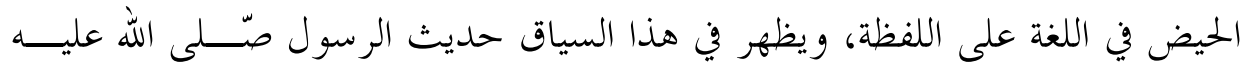

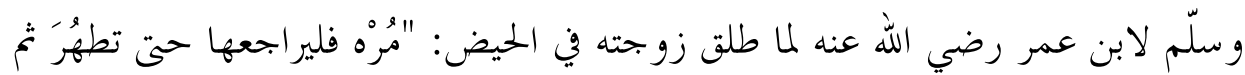

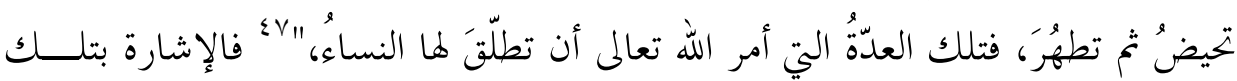

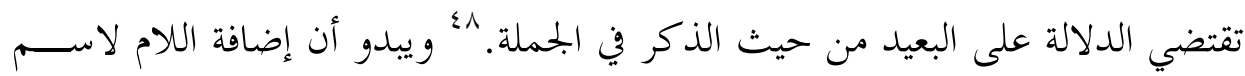
الإشارة له علاقة بدلالتي القرب و البعد على ما يقرره النحاة. 9؛ وفي هذا السياق يمكن

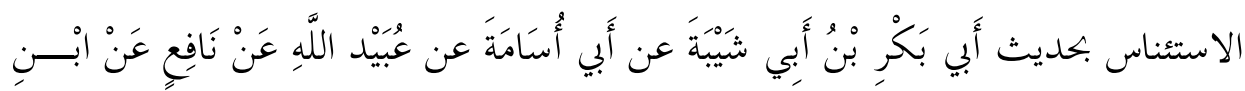

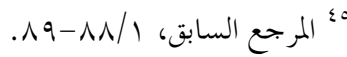

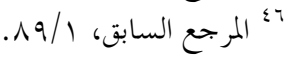

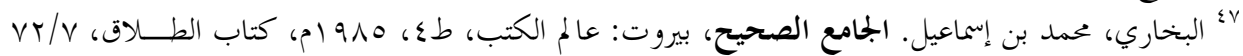
رقمبهن البحاري،

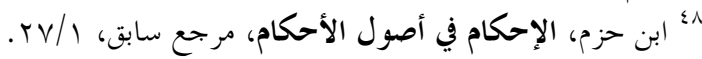

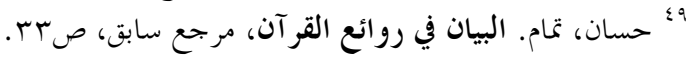




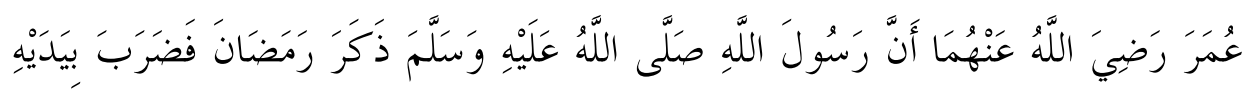

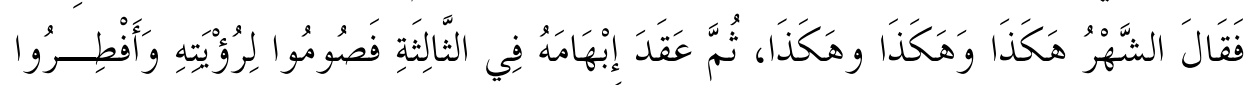

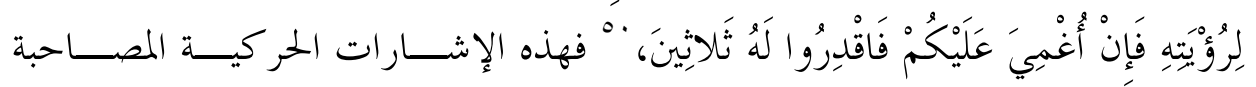
للكلام بتعل من القول فعلا.

ولعل أهم الموضوعات المتعلقة بكيفية استعمال اللغة وتداولها وفهمها، والتي عرض

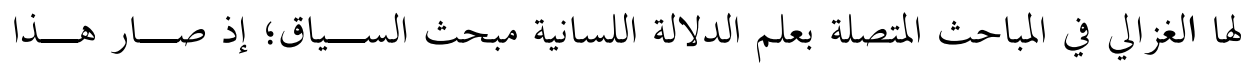

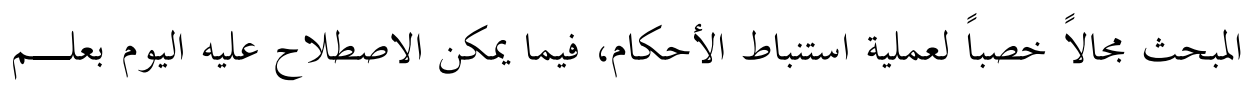

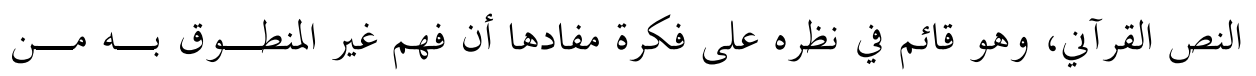

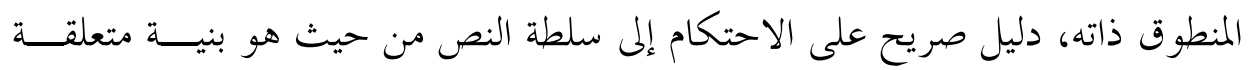

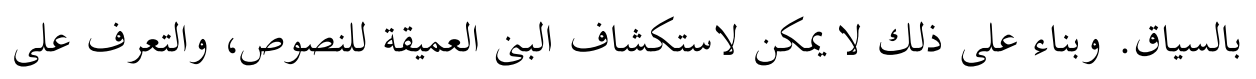

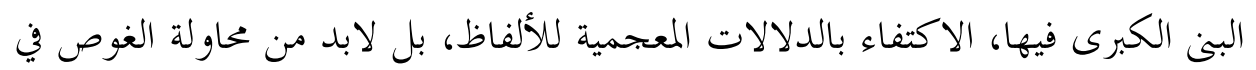

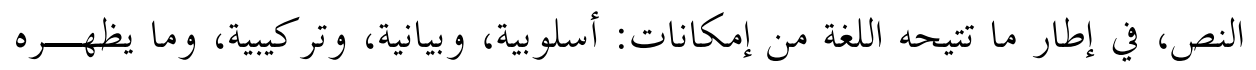

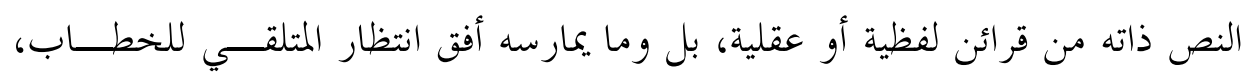

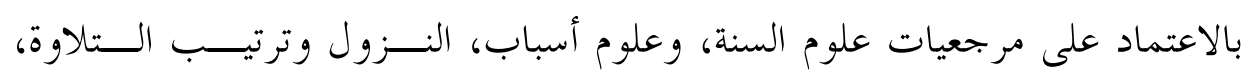

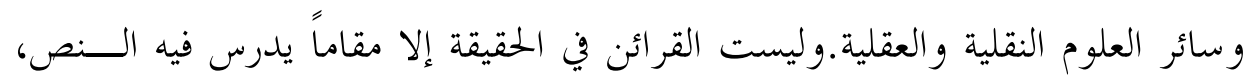

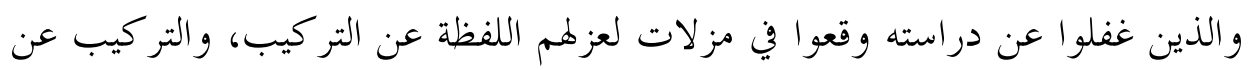

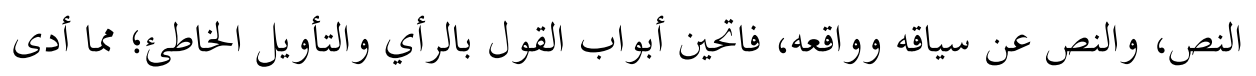
إلى ظهور الفرق الإسلامية.

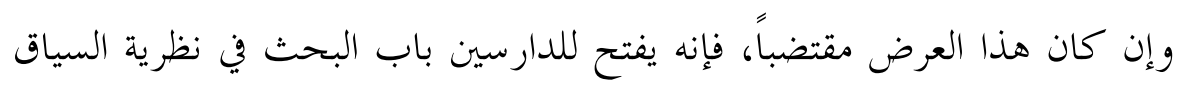

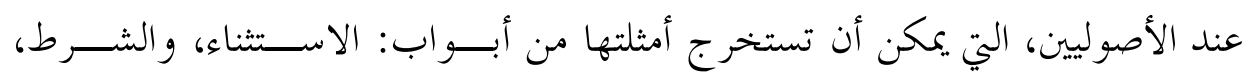

• مسلم، مسلم بن الحجاج القشيري. الصحيح، ومعه شرح صحيح مسلم للنووي، بيروت: دار الكتب العلمية،

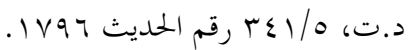




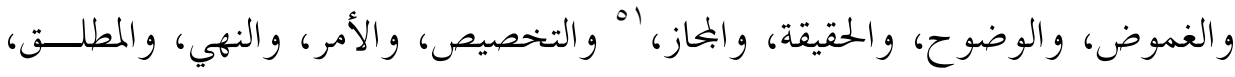

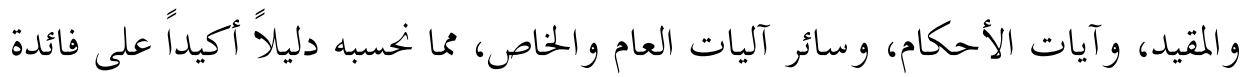
السياق اللغوي والحالي في تحديد الدلالة العامة للنصوص.ومن صور العناية بالسياق في

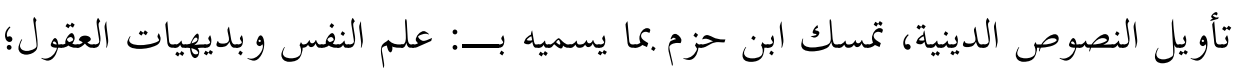

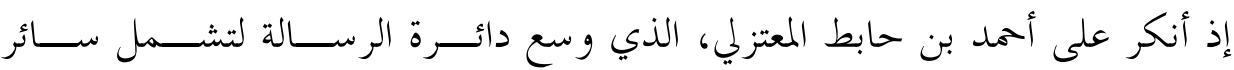

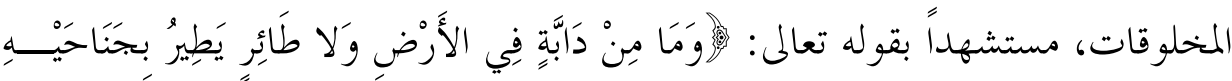

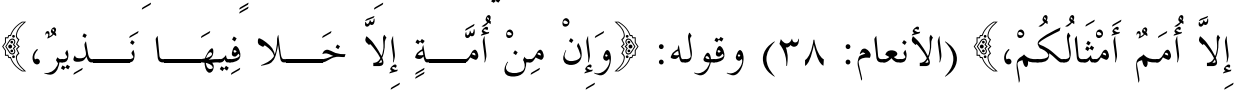

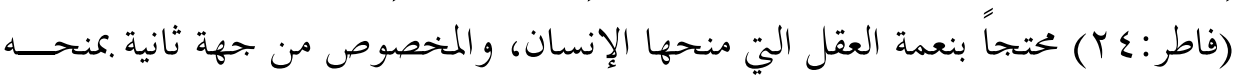

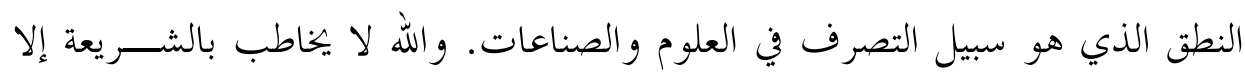

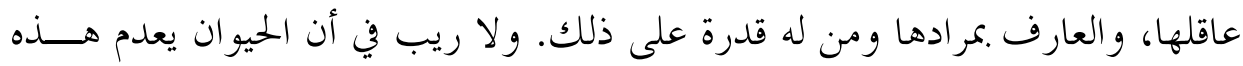

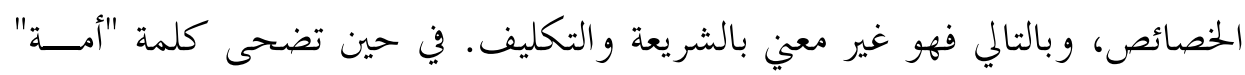

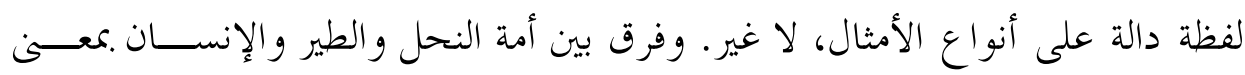
النوع، أمم الناس .معنى قبائلهم وطو ائفهم وحاضرهم وغائبهم.

وفي رد ابن حزم على مزاعم ابن النغريلة اليهودي، دليل آخر على فهـــمـ المقــــام

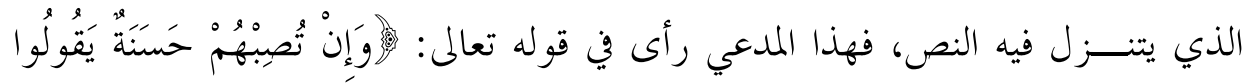

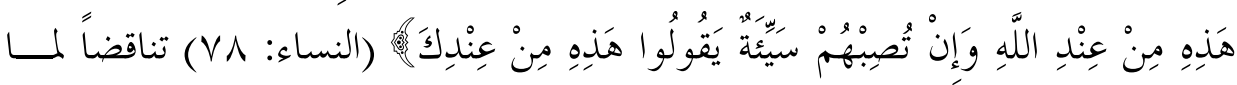

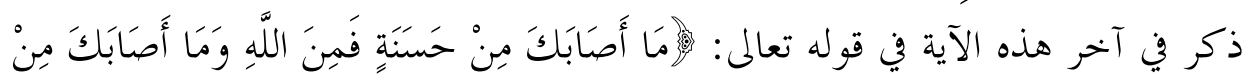

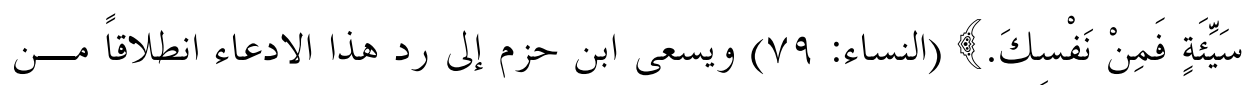

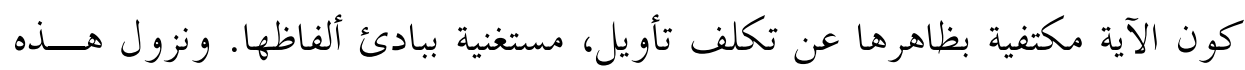

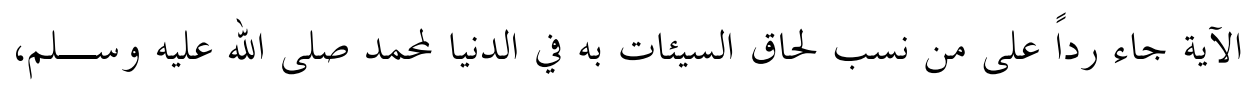

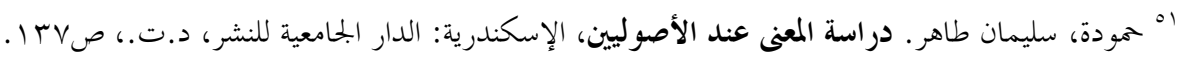

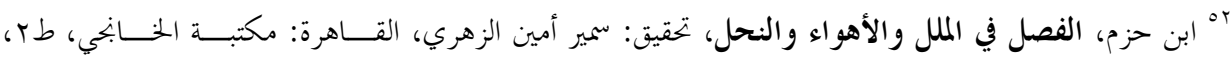


بأن الإنسان يجيني ما كسبت يداه من تقصير أو أداء للو اجبات، وكلٍ مــنـ عنـــــ الله

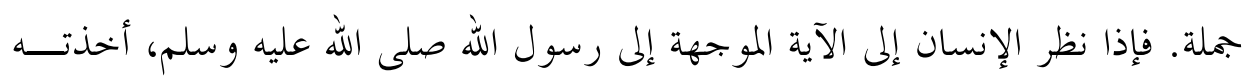

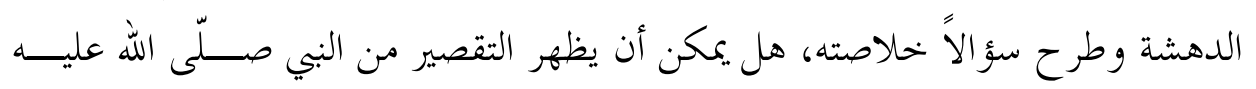

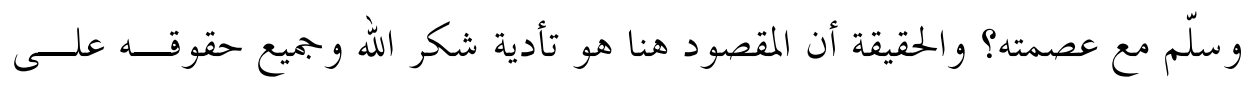

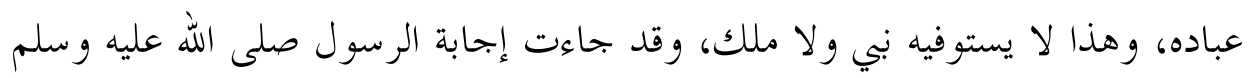

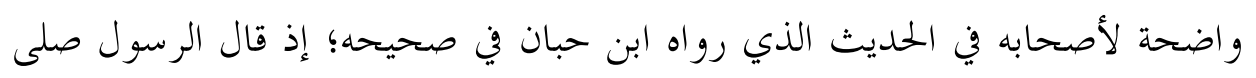

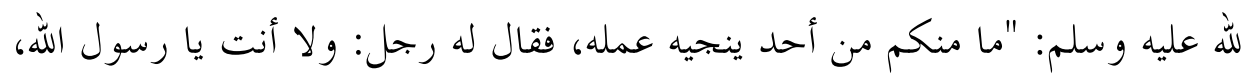

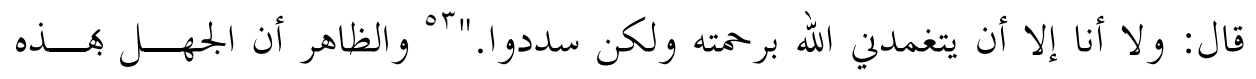

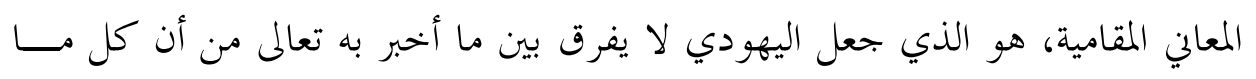

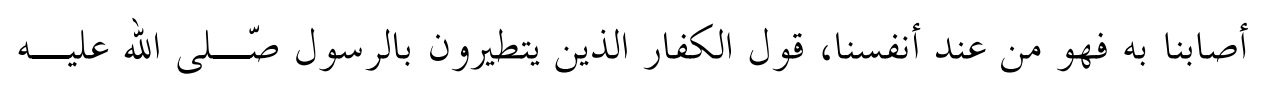
و سلم وصحبه.

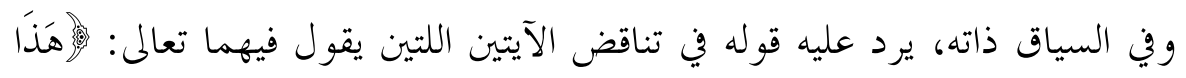

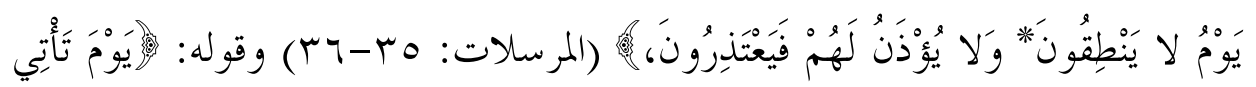

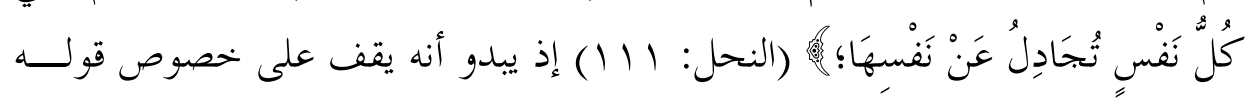

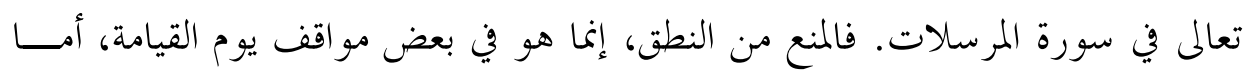

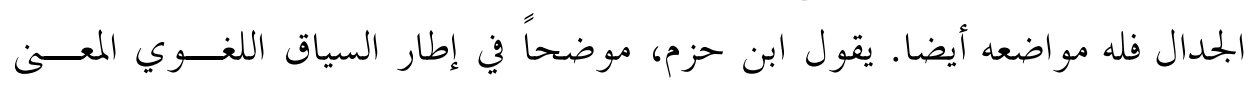

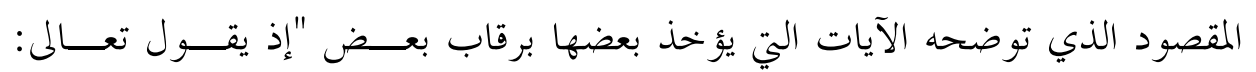

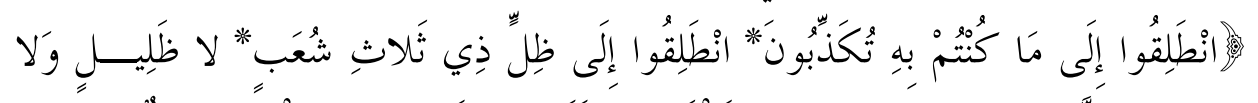

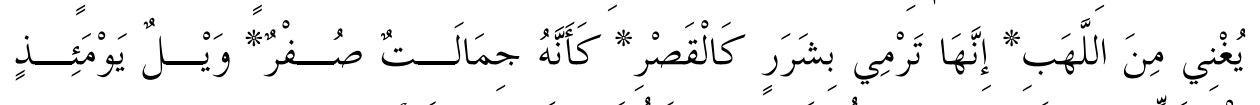

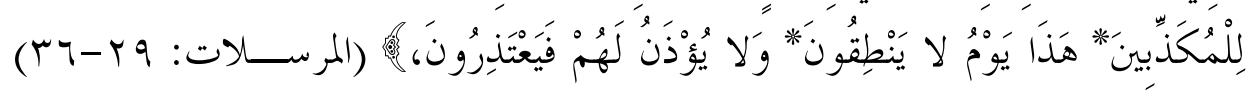

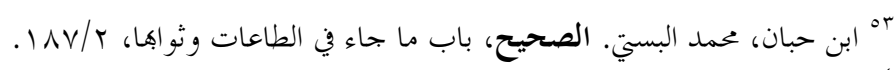

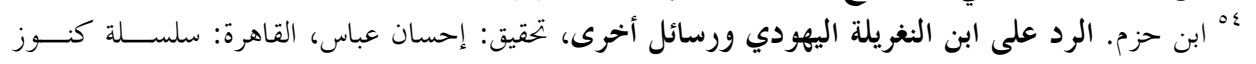

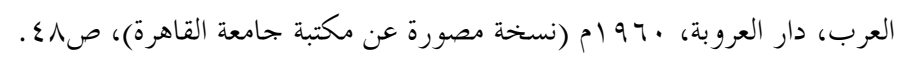


أي و لا يؤذن لهم فيه بعذر، وهكذا نصٌٌ الآيات متتابعات لا فصل بينها، فيصــح أن

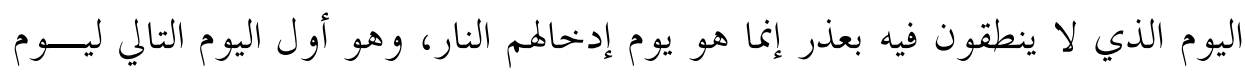

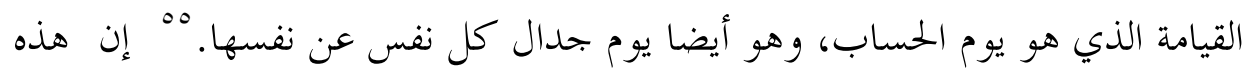

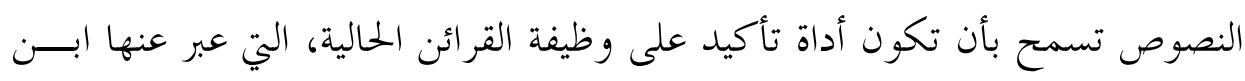
حزم بعلم النفس وبديهيات العقل في تخصيص الدلالة العامة، وتحديد معاني الوحدات

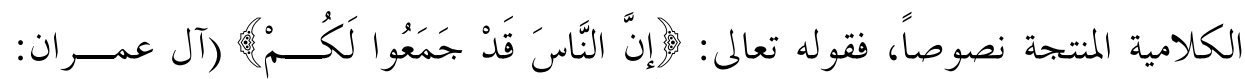

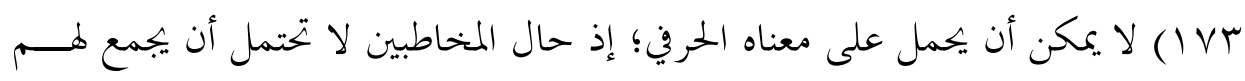
كل الناس على سبيل الحقيقة، إنما بعضهم، و الدليل على ذلك القرينة العقلية.

ويمكن حصر القرائن الحالية في القرينة العقلية (بديهيات العقل)، ووظيفتها منــع

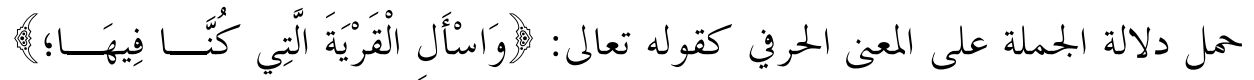

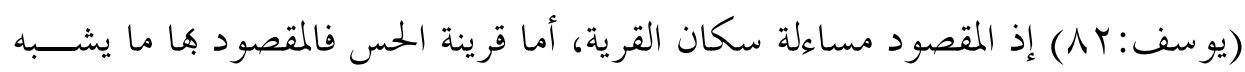
الواقع أو ينفيه مما يذكره النص أو ينفيه، ووظيفة هذه القرينة تصديقية برهانية، ومثال

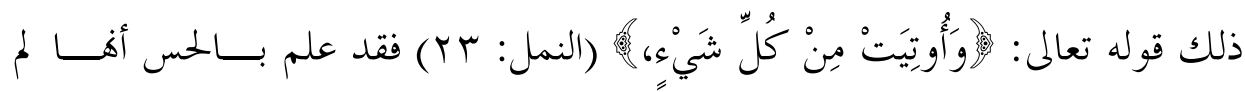
تؤت ما أوتي سليمان، وتظل فكرة القرائن بعد ذلك أساساً مهماً في التحليل النصــي لهي

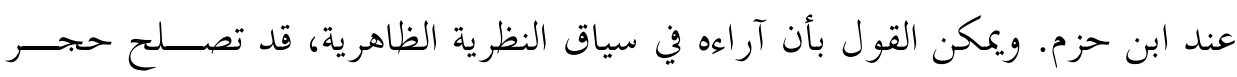
أساس في بناء نظرية سياقية كاملة، لها تقنينها وتمثلاتها التطبيقية. ولعل مباحث العموم والخصوص عنده، وتكامل النصوص، ومراتب الدلالة التركيبية، من حيث الوضــوح و الغموض، صورٌ هذا الجانب. ولنا أن نتوقف مع مفهوم ميز ظهر عند الأصوليين هو مفهوم الاقتضاء، والمقصود به دلالة اللفظ على المسكوت عنه؛ إذ يتوقف صدق الكلام

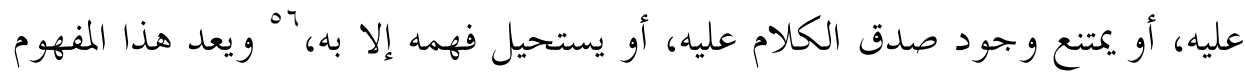

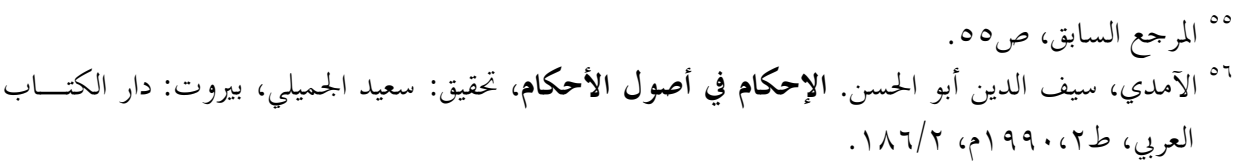




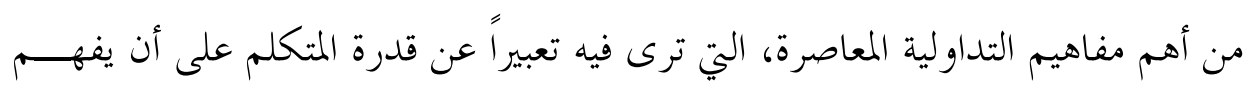

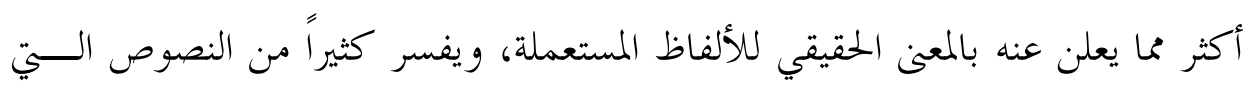

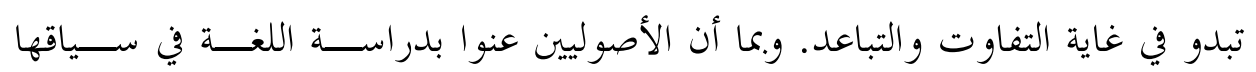

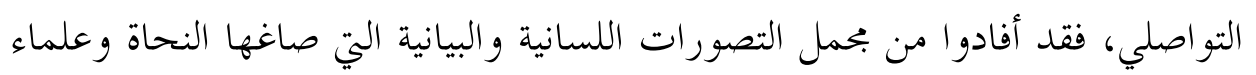

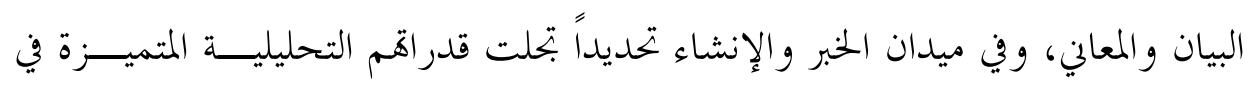

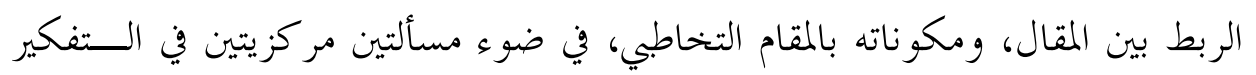

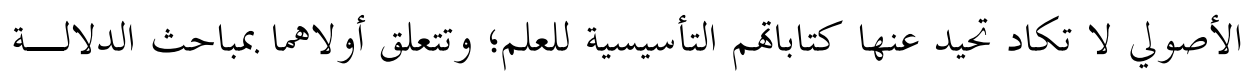

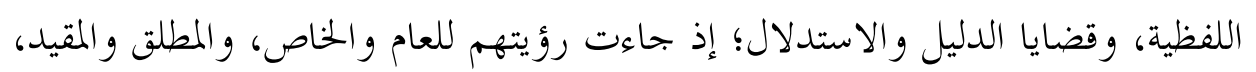

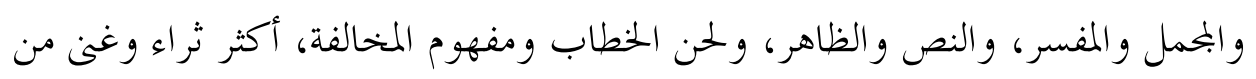

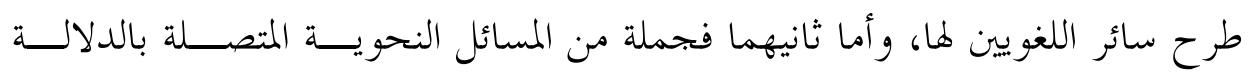

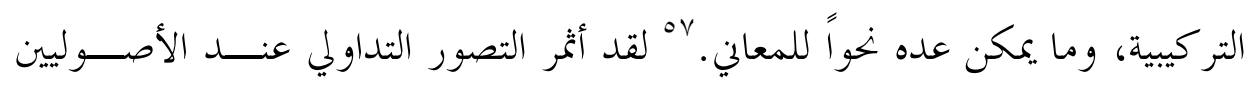

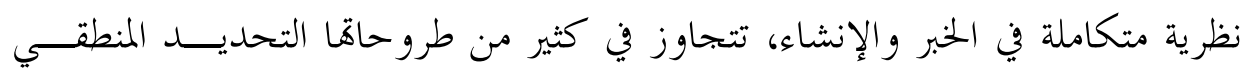

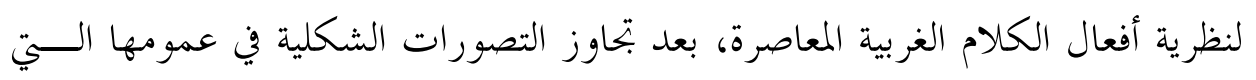

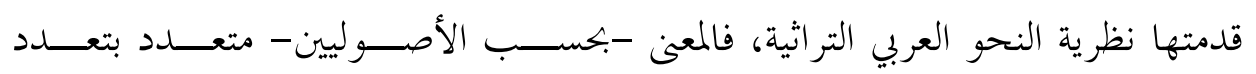

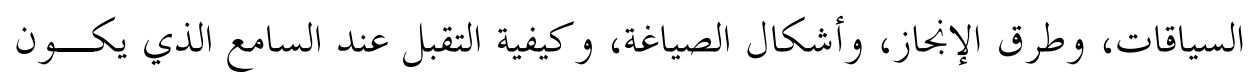

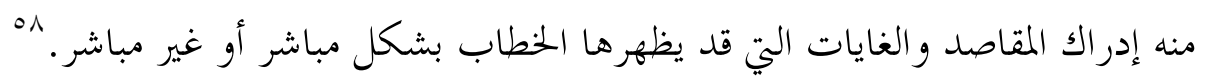
ولنا أن نتوقّف -مثلا- عند رؤيتهم للخبر في بعده السياقي؛ إذ يتحول من الدلالة

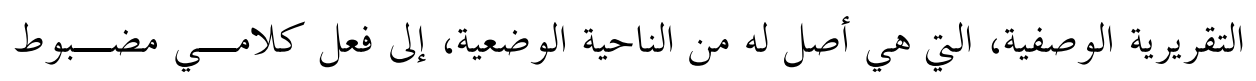

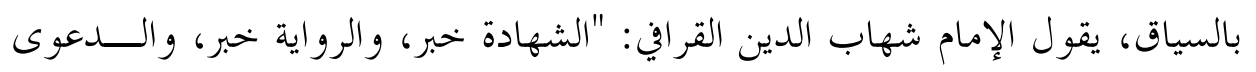

"ه جمال الدين، مصطفى. البحث النحوي عند الأصوليين، بغداد: دار الرشيد، منشورات وزارة الثقافة الإعلام،

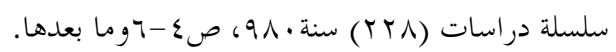

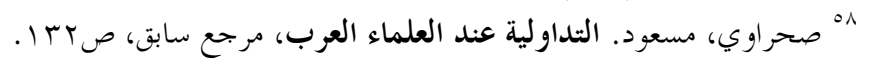


خبر، والإقرار خبر، والمقدمة خبر، و النتيجة خبر ... فما الفرق بين هذه الأخبــار؟"هـهـ ونود التنبيه في هذا السياق إلى أن الرواية فيما قرره القرافي متصلة بعموم المخبَر عنــه، بينما تكون الشهادة في الخاص منه، ومن جهة السياق الاجتماعي يمكن ربط الروايــة بالمقام غير الرسمي، في حين تناط الشهادة بالمقام الخاص المتمثل في القضاء، وشــــــادة الشهود التي يشترط لها شروط صحة هي: الحرية والذكورة والعدد، لافتاً إلى إمكـــان

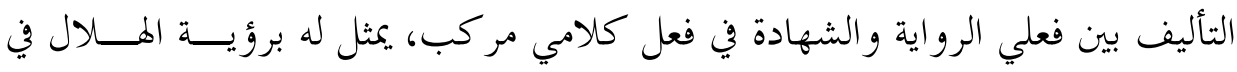
رمضان، فهو شهادة ورواية في الآن نفسه في سياق الفعل الإخباري الكلي، لَ ويوجّه القرافي في فعل الشهادة إلى إمكان تحوله إلى فعل إنشائي صريح على صيغة: أشهد أن

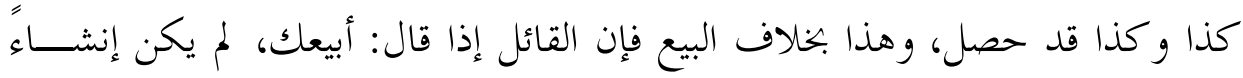
للبيع بل إخباراً به، أو وعداً به في المستقبل، ولو قال: بعتك كال كان بيعا محققا، فالإنشاء في الشهادة بصيغة المضارع، وفي العقود بالماضي، مما يعني ضرورة إدراج فعل الشهادة

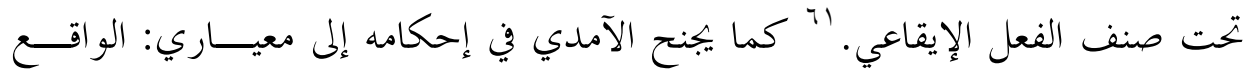
و القصدية، بَ اللذين استندت إليهما اللسانيات التداولية في تمييز الفعل الوصفي والفعل غير الوصفي، لكي ينضبط الخبر من حيث الأنواع التي يمكن إجمالهما في الخبر الصادق

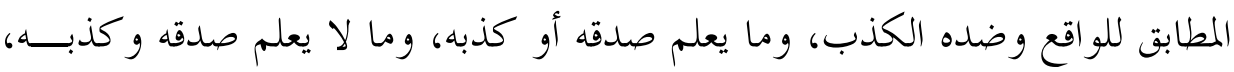

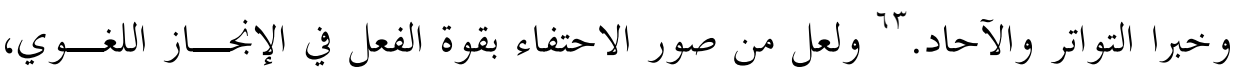
تركيزهم على عدم الأخذ بالشاذ و النادر من أقو ال العرب في الاســــلال الشـــــي،

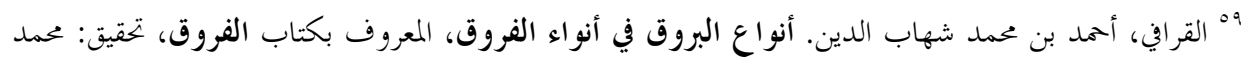

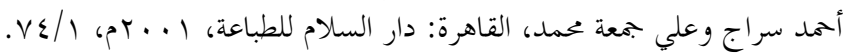

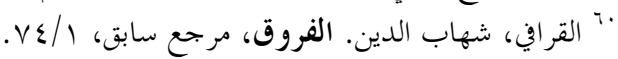

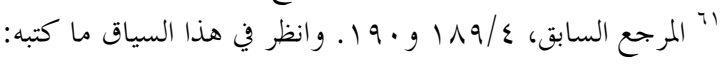

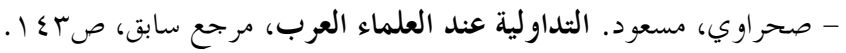

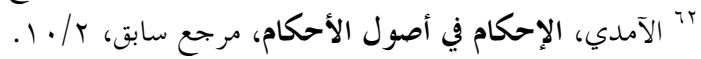

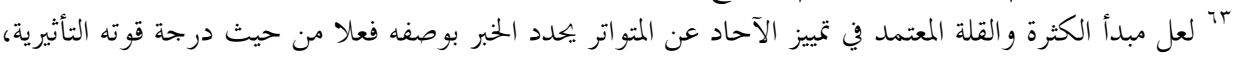

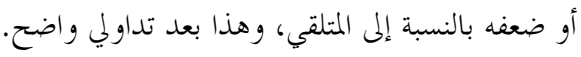




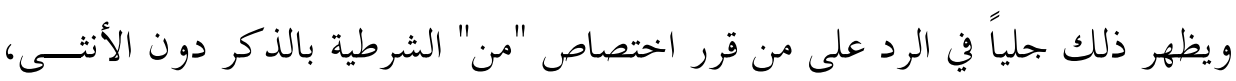

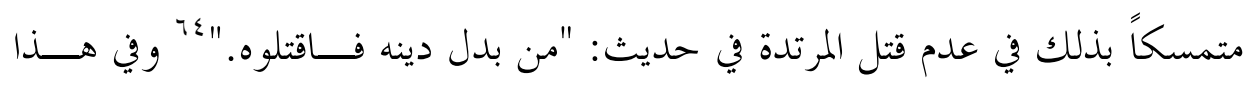

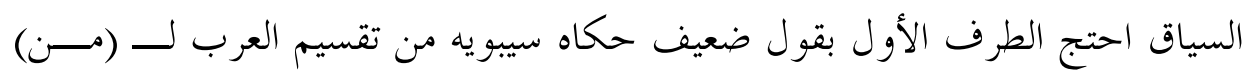

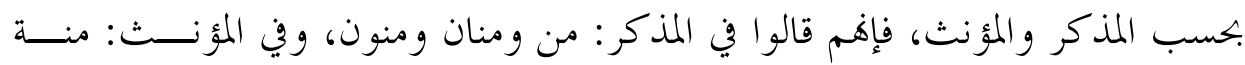

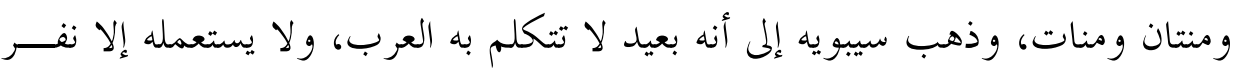

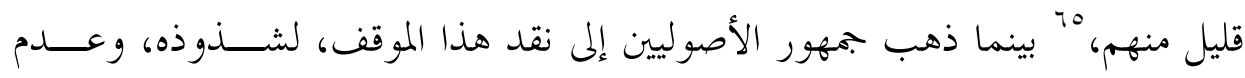

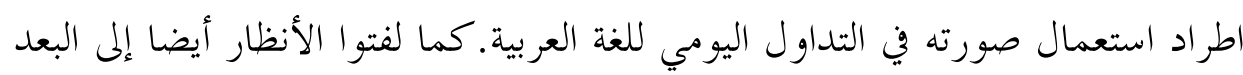

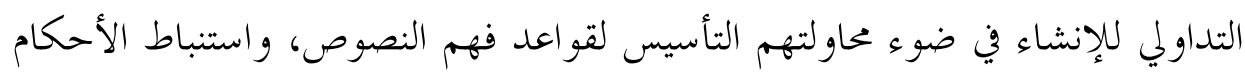

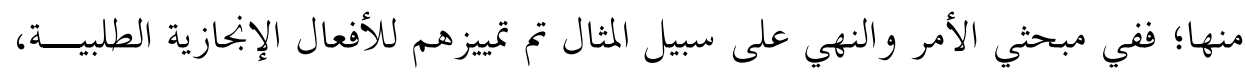

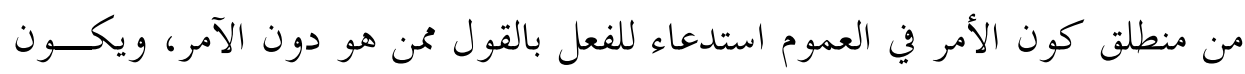

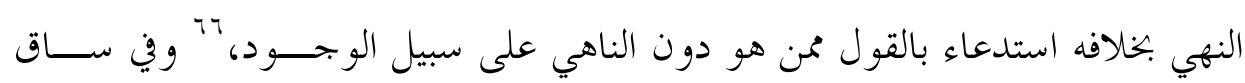

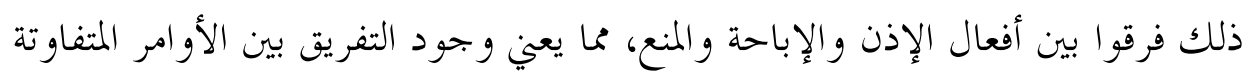

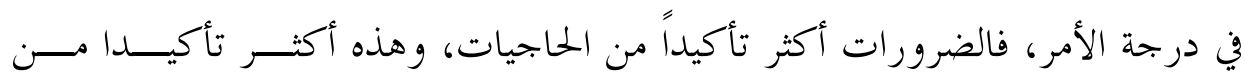

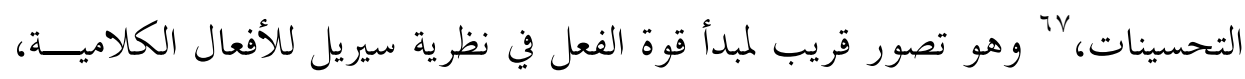

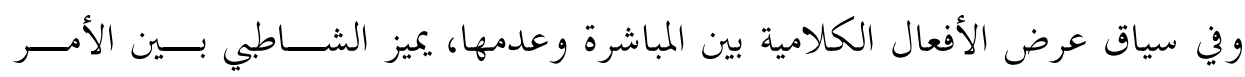

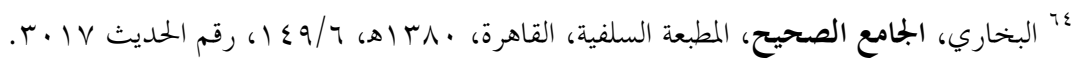

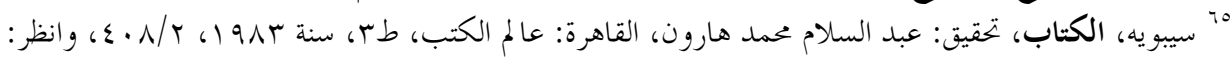

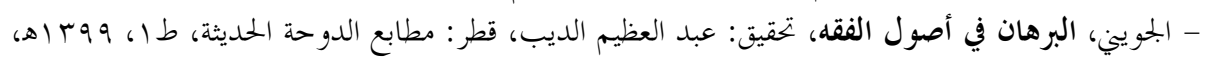
$.47 . / 1$ - كريري، محمد. في دراسته أسلوب الثرط بين النحويين والأصوليين، الرياض: سلسلة وزارة التعليم العالي

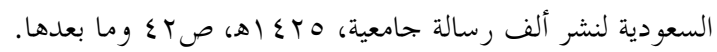

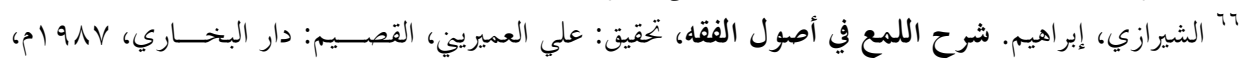

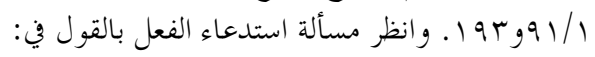

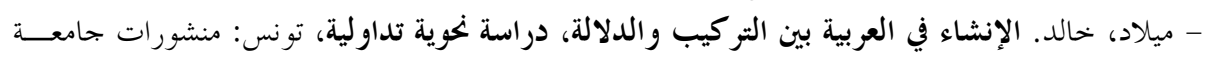

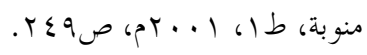

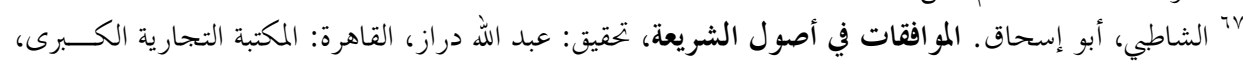


الصريح وغير الصريح، فالصريح نوعان: أولمما بحرد من العلة مثــل قولـــهـ تعــالى:

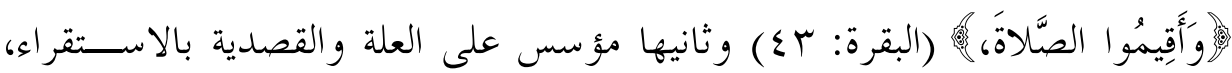

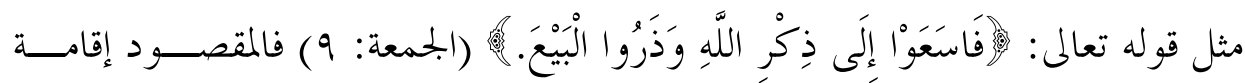

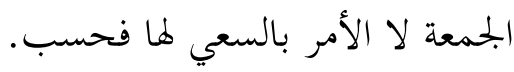

وأما الأمر غير الصريح، فعلى وجوه كثيرة لعل أهمها: الإخبار عن تقرير الحلكـــم،

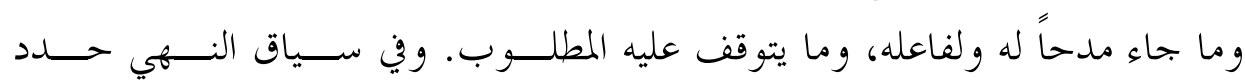
الأصوليون مفهومه انطلاقا من مبدأ المنع الذي صاغه الفارابي في كتابه الحـــروف، تم

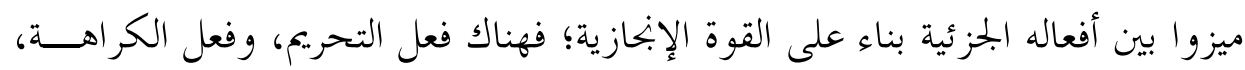

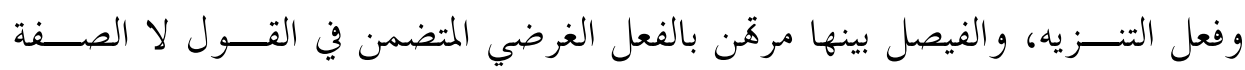
فحسب. ولعل عناية الأصوليين بصيغة التعجب من حيث هي قول دال علــى فعـلـ بـ

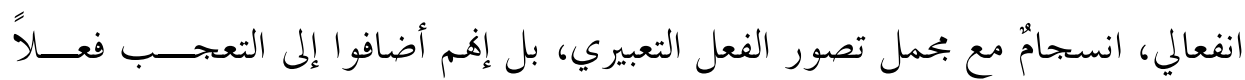

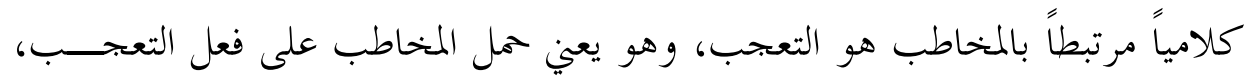

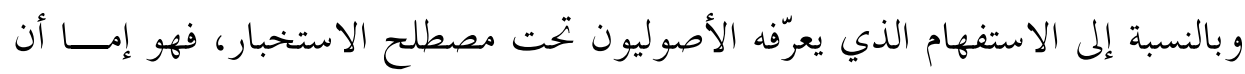

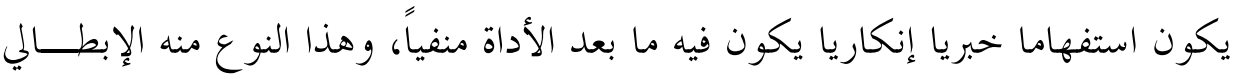

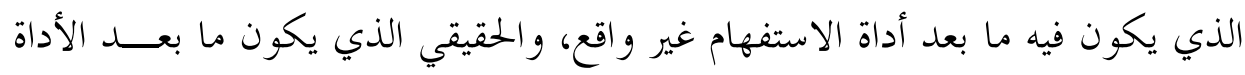

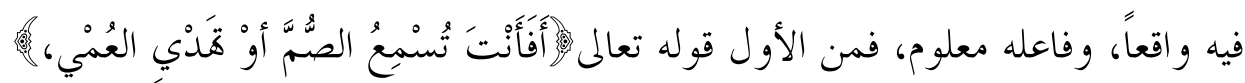

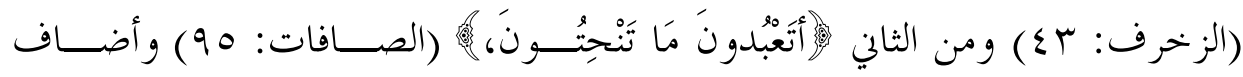
الزركشي الاستفهام التقريري الذي يممل فيه المخاطَب على الاعتراف بأمر قد قد استقر

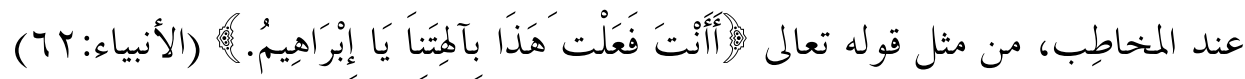

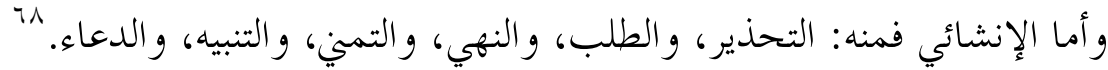

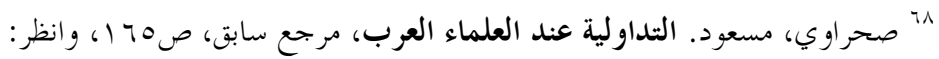

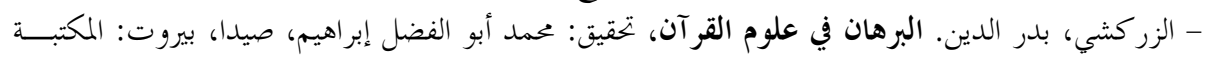

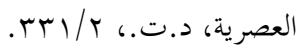




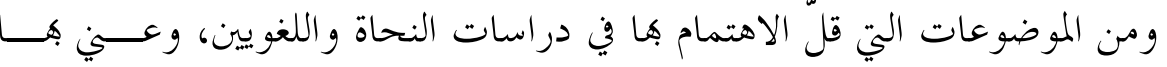

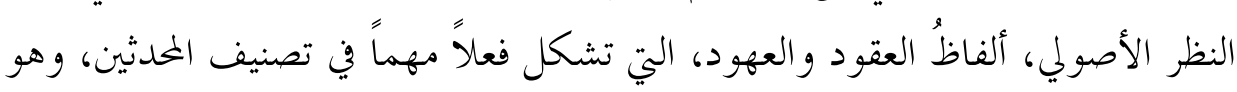

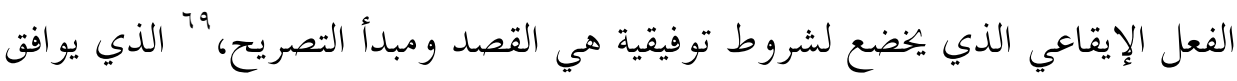
الفعل المباشر عند أوستن، فلو أخذنا -مثلا- فعل الطلاق فإنه سينجز بأفعال الكامية التالية؛ إذ بعضها مباشر والآخر غير مباشر، فيقال: أنت طالق، حبلك على غاربـــك، الحقي ببيت أهلك، اعتدّي، استبئي، تقنعي اتساقا مع الفكرة التي قررها الغزالي، التي تعلي من شأن الاحتفاء بالمقاصد والغايات دون الألفاظ والمباني، يقول الغزالي فيما نقله

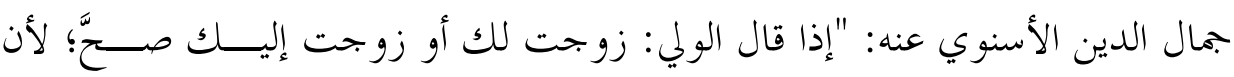

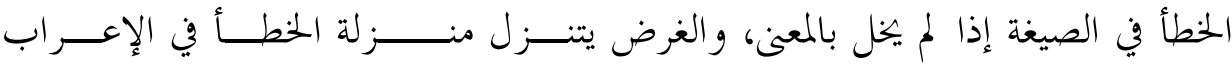

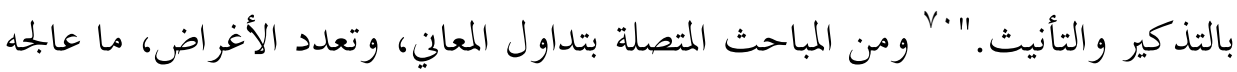

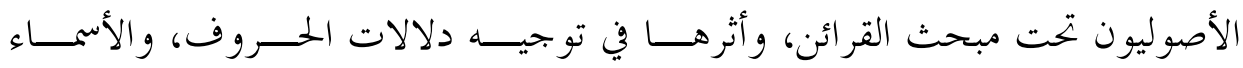
المشتركة، والمتر ادفة، والمتضادة، ومن خلال النظر فيما كتب في مباحث الحـــروف -

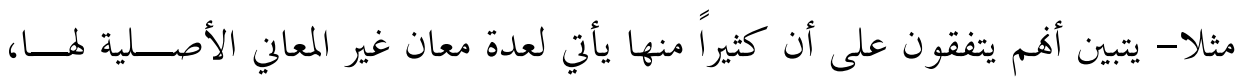

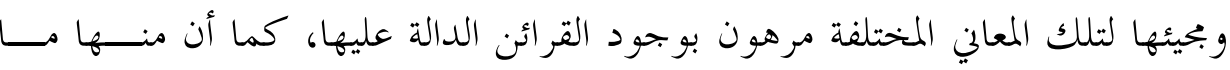

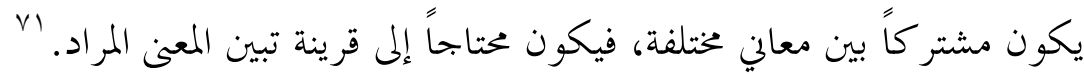

\section{ثالثاً: الأفعال الكلامية عند الأصوليين}

تتجلى ملامح نظرية الأفعال الكلامية عند الأصوليين، من خلال تتبع جهـــودهم التي سلكت مسارين متكاملين، يخدمان الخطاب القرآي في تمظهره البياني، من خــالـل

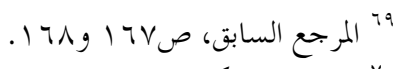

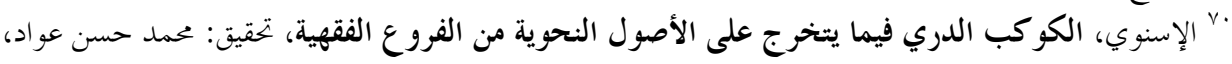

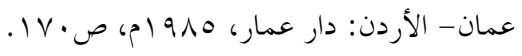

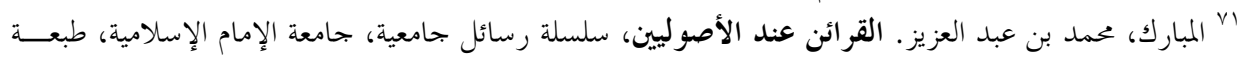

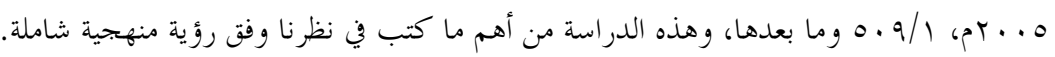


نظرية الإعجاز. ـ ويعبّر هذان المساران عن ترابط البنية الشكلية بالاستعمال و التـــداول،

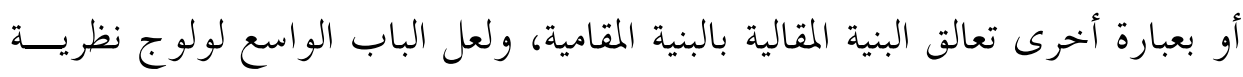
الفعل الكلامي في صورةا العامة، و التأسيس لنموذج عربي طموح هــــا، هـــو بــــاب الأساليب الإنشائية في علم المعاني، الذي لاقى عناية بالغة في كتابات علمـــاء النقـــل و العقل في المعرفة الإسلامية، و تتأسس نظرية الفعل الكامي على قاعدتين هما: العرف

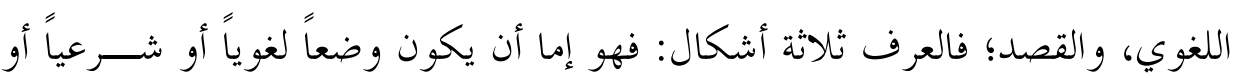

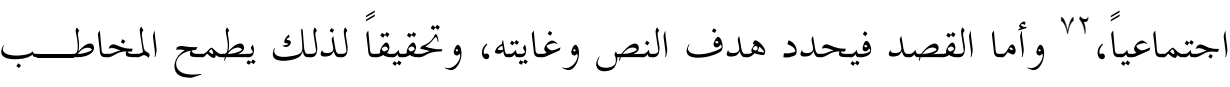
إلى أن يكون كلامه مفهوماً ودالاً دلالة يحسن السكوت عليها، مراعياً في ذلك تفاوت درجات المخاطبين في الفهم. وبالرغم من توحد المعرفة العرفية بالأوضاع اللسانية، فإن على المخاطب أن يهتم بأنواع القرائن اللسانية والمقامية، ليجلي ما غمض من دلالات مقصودة. ور.ما هذا ما يُفهم من نص ابن القيم حين حذر من إهمال قصد الخططـاب، فهو يقول: "فإياك أن تمل قصد المتكلم و نيته وعرفه، فتجني عليه وعلى الشريعة. Vr" ونستنجد في سياق تعريف الفعل الإيقاعي بالتصور الأصولي، الذي يقرر وجود أقوال

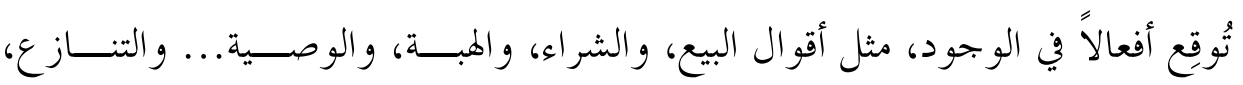

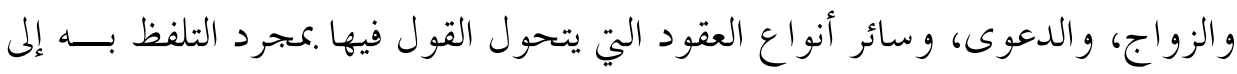
فعل ملزم واقع.ويقوم الفعل الإيقاعي في التصور الأصولي على عدد من القواعد منها:

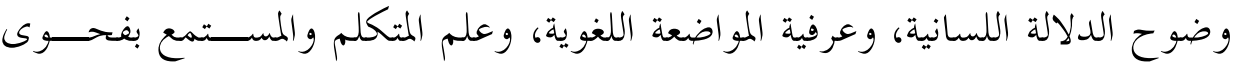

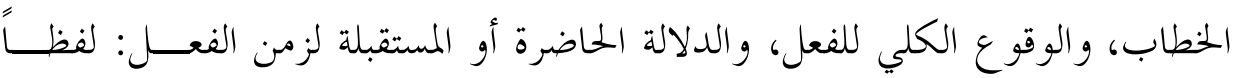

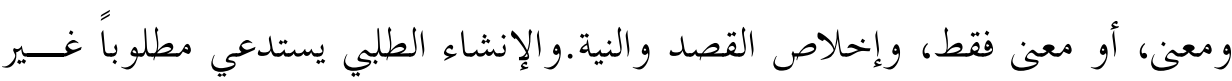

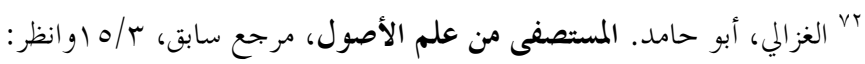

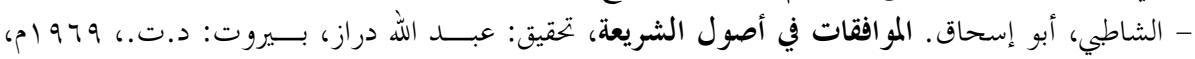
. r so/r

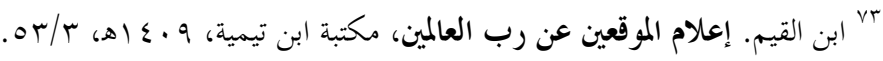


حاصل وقت الطلب؛ إذ يتأخر وجود معناه عن وجود لفظه، ويوافق هذا النوع مــــا اصطلح عليه حديثا بالإعلانيات. كما أبان الدرس الأصولي عن ماهية الفعل الطلـبـي،

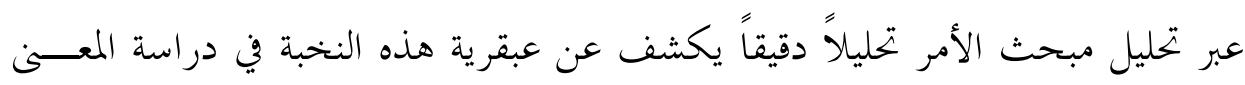
وتحليل الخطاب، ذلك أن هذا المبحث -بالذات- يعد جوهر القضية الاجتهاديسـة في تفسير النصوص، ومن بين المسائل المهمة عندهم البحث في صفة الأمر، ودلالاتسـه في المو اضعة والاستعمال، وعطف الأوامر وتكرارها، و وإمكان تراخيها في الزمان والمكان،

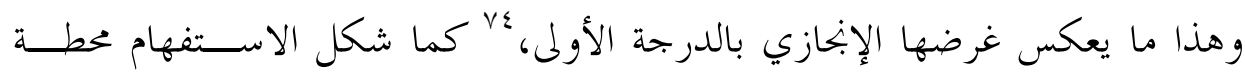

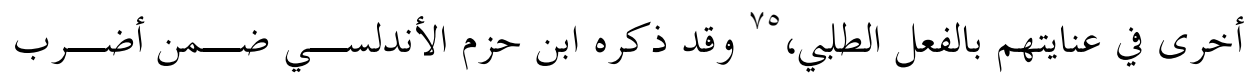

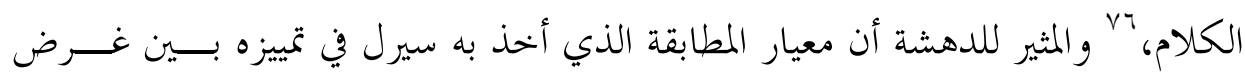

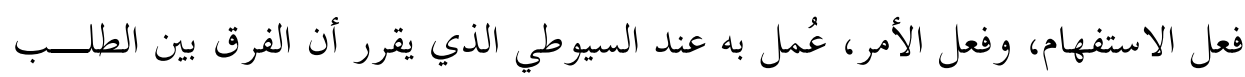
في الاستفهام و الطلب في الأمر والنهي والنداء واضح، فإنك في الاستفهام تطلب ما هو في الخارج ليحصل في ذهنك نقش له مطابق، وفيما سواه تنقش في ذهنك، ثم تطلـــبـ

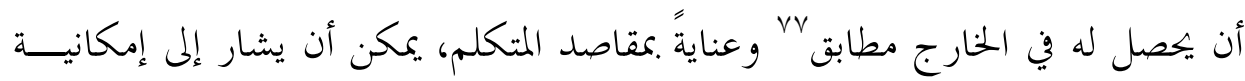

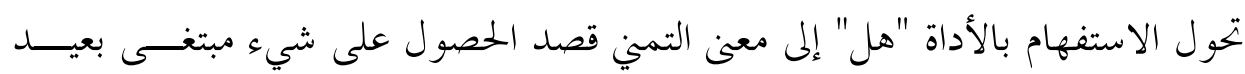

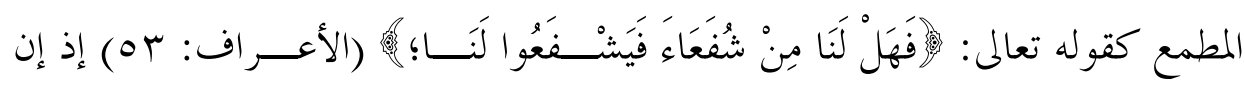

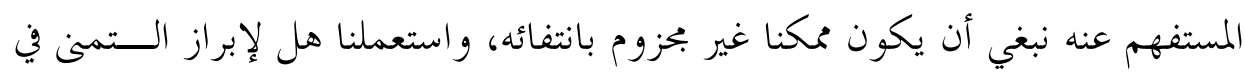
صورة الممكن إظهار شدة الرغبة فيه.

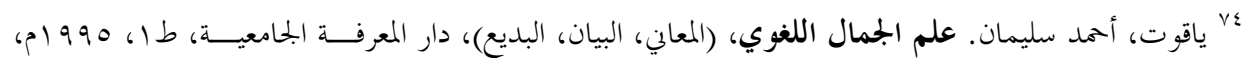

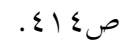

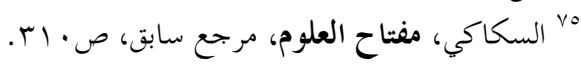

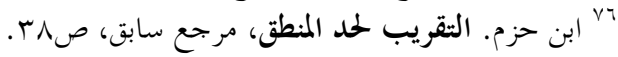

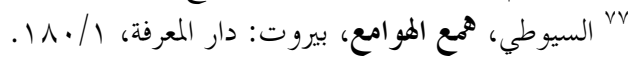

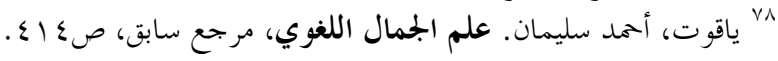


إن النظر إلى طبيعة العلاقة بين المتكلم والمخاطب، يحدد غرض الخطاب ودرجته،

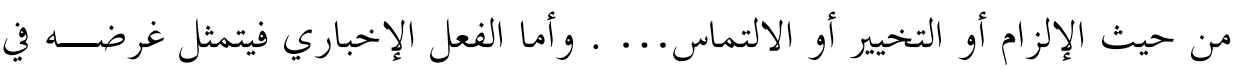

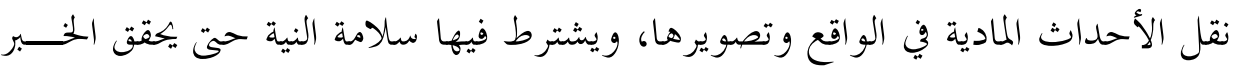

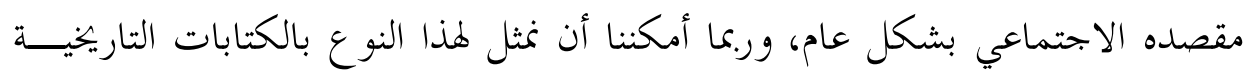

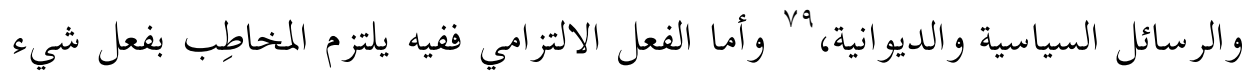

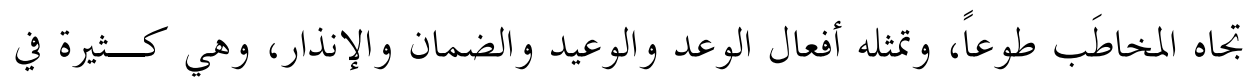

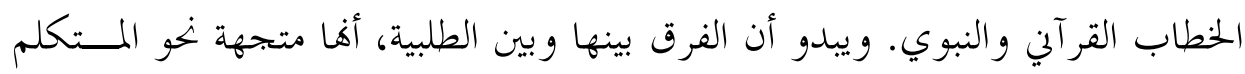

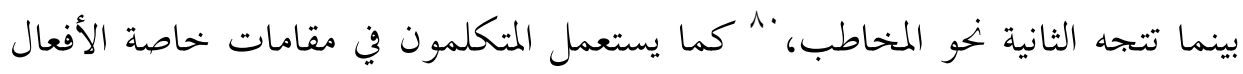

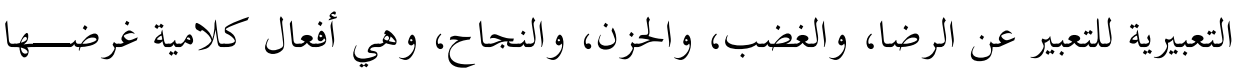

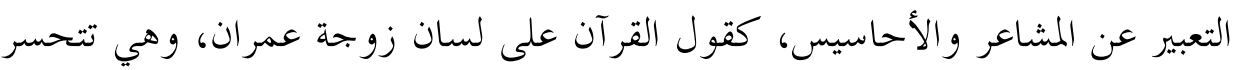

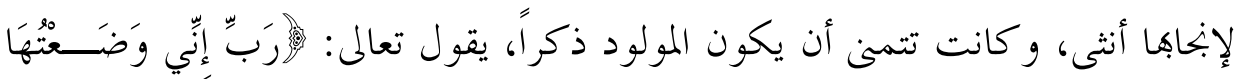

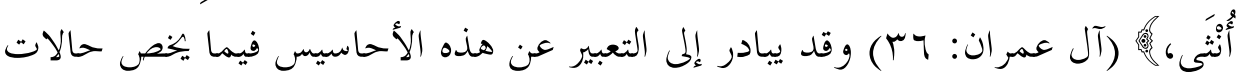

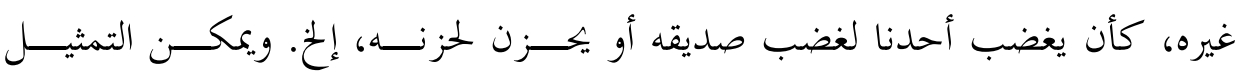

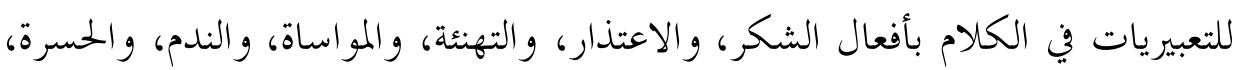
والشوق، والرضا، والغضب.

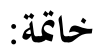

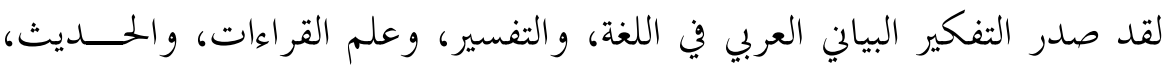

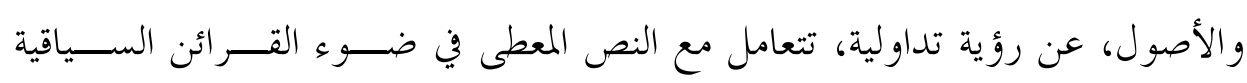

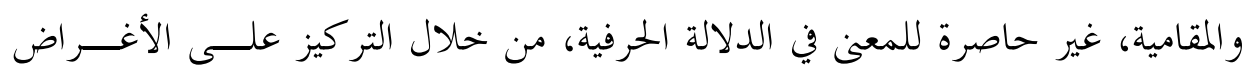

"طبطائي، طالب سيد هاشم. نظرية الأفعال الكلامية بين فلاسفة اللغة المعاصـرين والبلاغـيين العـرب،

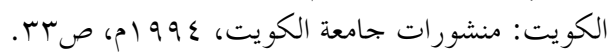

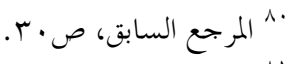

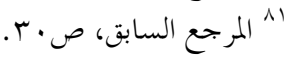


و المقاصد الأساسية للكلام. وهذا يجعلنا نقرر أهمية ما توصل إليه الفكر العربي الأصيل

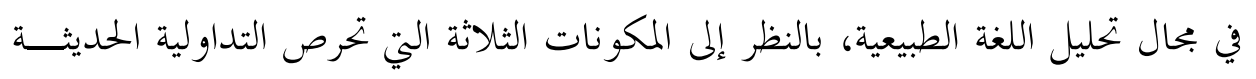

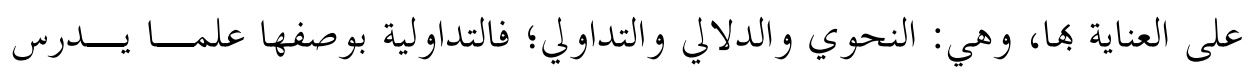

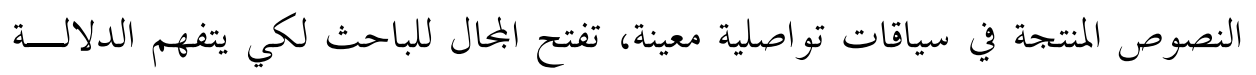

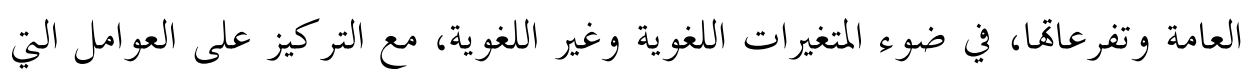

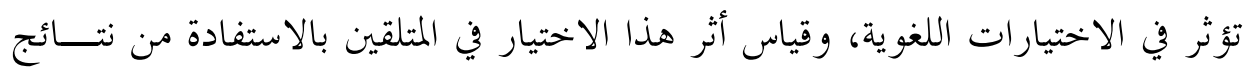

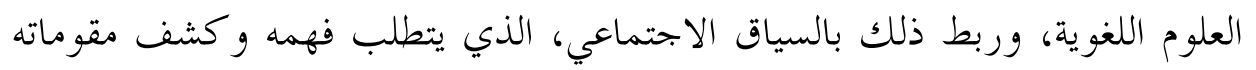

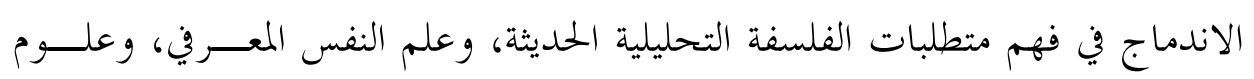

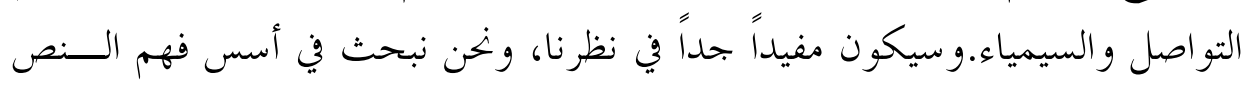

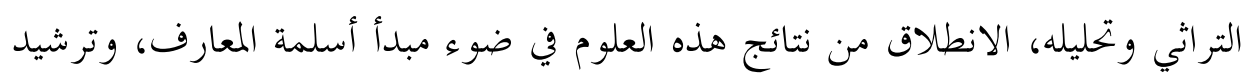

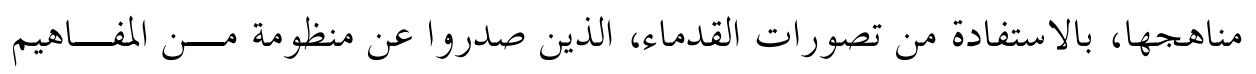

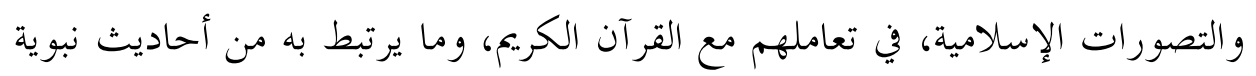

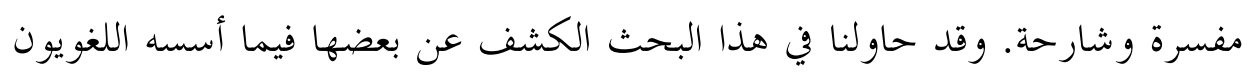

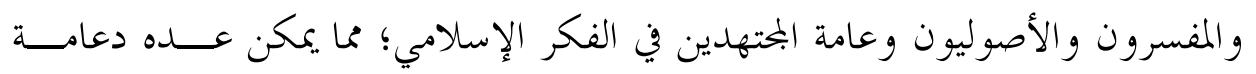

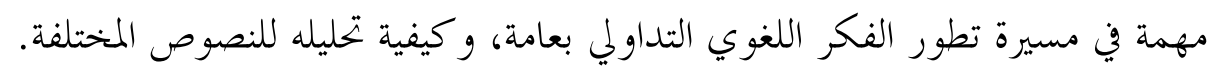

